\title{
Species interactions can shift the response of a maerl bed community to ocean acidification and warming
}

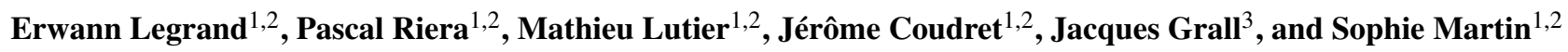 \\ ${ }^{1}$ Sorbonne University, UPMC, Station Biologique, Place Georges Teissier, 29688 Roscoff CEDEX, France \\ ${ }^{2}$ CNRS, Station Biologique, Place Georges Teissier, 29688 Roscoff CEDEX, France \\ ${ }^{3}$ UBO, IUEM, Place Nicolas Copernic, 29280 Plouzané, France
}

Correspondence to: Erwann Legrand (erwann.legrand@sb-roscoff.fr)

Received: 20 June 2017 - Discussion started: 29 June 2017

Revised: 20 October 2017 - Accepted: 25 October 2017 - Published: 30 November 2017

\begin{abstract}
Predicted ocean acidification and warming are likely to have major implications for marine organisms, especially marine calcifiers. However, little information is available on the response of marine benthic communities as a whole to predicted changes. Here, we experimentally examined the combined effects of temperature and partial pressure of carbon dioxide $\left(p \mathrm{CO}_{2}\right)$ increases on the response of maerl bed assemblages, composed of living and dead thalli of the free-living coralline alga Lithothamnion corallioides, epiphytic fleshy algae, and grazer species. Two 3month experiments were performed in the winter and summer seasons in mesocosms with four different combinations of $p \mathrm{CO}_{2}$ (ambient and high $p \mathrm{CO}_{2}$ ) and temperature (ambient and $+3{ }^{\circ} \mathrm{C}$ ). The response of maerl assemblages was assessed using metabolic measurements at the species and assemblage scales. This study suggests that seasonal variability represents an important driver influencing the magnitude and the direction of species and community response to climate change. Gross primary production and respiration of assemblages was enhanced by high $p \mathrm{CO}_{2}$ conditions in the summer. This positive effect was attributed to the increase in epiphyte biomass, which benefited from higher $\mathrm{CO}_{2}$ concentrations for growth and primary production. Conversely, high $p \mathrm{CO}_{2}$ drastically decreased the calcification rates in assemblages. This response can be attributed to the decline in calcification rates of living $L$. corallioides due to acidification and increased dissolution of dead $L$. corallioides. Future changes in $p \mathrm{CO}_{2}$ and temperature are likely to promote the development of non-calcifying algae to the detriment of the engineer species L. corallioides. The development of fleshy algae may be modulated by the ability of grazers to regulate epiphyte
\end{abstract}

growth. However, our results suggest that predicted changes will negatively affect the metabolism of grazers and potentially their ability to control epiphyte abundance. We show here that the effects of $p \mathrm{CO}_{2}$ and temperature on maerl bed communities were weakened when these factors were combined. This underlines the importance of examining multifactorial approaches and community-level processes, which integrate species interactions, to better understand the impact of global change on marine ecosystems.

\section{Introduction}

A growing body of literature predicts that ocean acidification and warming will be the main anthropogenic drivers affecting marine species by the end of the century (Kroeker et al., 2013). Due to the increase in atmospheric $\mathrm{CO}_{2}$, seawater surface temperatures have been predicted to increase by $0.71-$ $2.73{ }^{\circ} \mathrm{C}$ and $\mathrm{pH}$ to decline by $0.07-0.33$ units in the surface ocean by the end of the 21 st century (Bopp et al., 2013).

Species interactions are a key element in ecosystem functioning and are likely to attenuate or amplify the direct effects of climate change on individual species (O'Connor et al., 2011; Hansson et al., 2012; Kroeker et al., 2012). Most research on benthic ecosystems has focused on the impact of ocean acidification and warming on the response of single species (Yang et al., 2016) and, despite a growing interest, studies examining the effects of climate change at the community scale are scarce (Hale et al., 2011; Alsterberg et al., 2013). Understanding the mechanisms and interactions that occur among marine communities that face the pre- 
dicted changes is necessary for a better overview of marine ecosystem response. Climate change is likely to strongly alter interactions between macroalgae (e.g. calcifying and noncalcifying macroalgae; Olabarria et al., 2013; Short et al., 2014, 2015), interactions between grazers and macroalgae (Poore et al., 2016; Sampaio et al., 2017), and prey-predator dynamics (Asnaghi et al., 2013; Jellison et al., 2016), inducing drastic consequences on the structure and functioning of marine ecosystems (Widdicombe and Spicer, 2008; Hale et al., 2011).

Maerl beds feature high structural and functional diversity arising primarily from the numerous species interactions that occur in this environment - in particular, interactions between fleshy and calcareous macroalgae and grazers and macroalgae (Hily et al., 1992; Guillou et al., 2002; Grall et al., 2006). The accumulation of living and dead thalli of freeliving coralline algae (Corallinaceae, Rhodophyta) creates a complex three-dimensional structure that provides habitat for many faunal and floral species (Foster et al., 2007; AmadoFilho et al., 2010; Peña et al., 2014), some of which have high commercial value (Grall and Hall-Spencer, 2003). In some locations, dead maerl can reach high proportions compared with living maerl (Hily et al., 1992), thereby contributing substantially to the local carbonate dynamics (Martin et al., 2007).

The main species inhabiting maerl beds may respond differently to ocean acidification and warming. Coralline algae are known to be among the most vulnerable species facing ocean acidification (McCoy and Kamenos, 2015; Martin and Hall-Spencer, 2016) due to their highly soluble Mg-calcite skeleton (Morse et al., 2006). The deleterious consequences of ocean acidification have also been demonstrated for other calcareous marine taxa, such as mollusks (Gazeau et al., 2013; Parker et al., 2013) and echinoderms (Dupont et al., 2010), with reductions in survival, growth, development, and abundance (Kroeker et al., 2013). Conversely, some species can benefit from the increase in $\mathrm{CO}_{2}$ concentration and temperature. Positive responses, such as increases in primary production and growth, have been found mostly among noncalcifying organisms, such as fleshy algae and seagrasses (Koch et al., 2013; Pajusalu et al., 2013).

Here, we experimentally investigated the impact of ocean acidification and warming on the metabolism and the interactions of the main maerl-forming species in Brittany Lithothamnion coralloides and the epiphytic fleshy macroalgae and main grazer (gastropods and sea urchins) associated with it. Because the response of species and communities to climate change is likely to vary depending on seasonal changes in environmental factors, such as light intensity, photoperiod, and temperature (Godbold and Solan, 2013; Martin et al., 2013; Baggini et al., 2014), it was tested in both winter and summer conditions. The response of marine communities to climate change is likely to be influenced by the direct effects of environmental stressors on individual organisms and by the indirect effects induced by shifts in interspe- cific interactions (Harley et al., 2012; Auster et al., 2013). In the present study, we therefore performed metabolic measurements at the species and at the community scale. At the species scale, studying species physiology is useful for understanding how organisms cope with changing climatic conditions and for analysing the community metabolic response. Community-scale measurements provide information on the potential shifts in species interactions induced by climate change. In particular, we tested the hypothesis that climate change will increase epiphytic fleshy algal growth, exacerbating the deleterious consequences of predicted changes on $L$. corallioides metabolism. We also investigated whether the predicted changes can modify interactions between grazers and macroalgae and their ability to regulate epiphytic biomass.

\section{Materials and methods}

\subsection{Species collection and assemblages}

Organisms were collected from a maerl bed in the Bay of Brest, France $\left(48^{\circ} 18^{\prime} \mathrm{N}, 4^{\circ} 23^{\prime} \mathrm{W}\right)$, using a naturalist's dredge (width: $1 \mathrm{~m}$; height: $0.2 \mathrm{~m}$; net: $1.5 \mathrm{~m}$ long) deployed from the research vessel Albert Lucas. In the Bay of Brest, maerl beds are located at depths of between 0.7 and $6.8 \mathrm{~m}$, according to the tide (Dutertre et al., 2015). We deliberately selected thalli of the maerl species $L$. corallioides Crouan and Crouan, 1867 that were devoid of any apparent epiphytes; nonetheless, they were not cleaned so as to retain any epiphyte spores that may have been present on their surface. Medium-sized individuals of the three main species of grazers living in maerl beds were also sampled: two gastropod species (sea snails), Gibbula magus Linnaeus, 1758 and $J u$ jubinus exasperatus Pennant, 1777, and an urchin species, Psammechinus miliaris Müller, 1771 (Grall et al., 2006). Samples were collected on 24 January 2015 (winter conditions) and 15 September 2015 (summer conditions). In each season, $1 \mathrm{~kg}$ of living thalli of $L$. corallioides, $500 \mathrm{~g}$ of dead thalli of $L$. corallioides, 40 individuals of G. magus (shell length range $17-29 \mathrm{~mm}$ ), 40 individuals of $P$. miliaris (test diameter range 11-23 mm), and 80 individuals of $J$. exasperatus (shell height range $5-11 \mathrm{~mm}$ ) were randomly selected and transported in seawater tanks to the Roscoff Marine Station. To mitigate the stress experienced by the species during sampling and transport, they were kept in open-flow aquaria at ambient $\mathrm{pH}$ and in situ temperature conditions at the time of collection for at least 1 week before starting the experiments. No mortality was recorded during this period.

\subsection{Experimental design}

Two 3-month-long experiments were conducted for both winter (March to June 2015) and summer (September to December 2015) conditions. For each season, 20 artificial assemblages were created and randomly assigned to twenty 
Table 1. Summary of the four experimental treatments. Two $p \mathrm{CO}_{2}\left(\right.$ ambient and high $\left.p \mathrm{CO}_{2}\right)$ and temperature (ambient and high temperature) conditions were tested. High $p \mathrm{CO}_{2}\left(\mathrm{H}-p \mathrm{CO}_{2}\right)$ corresponded to a $\mathrm{pH}$ decrease of -0.33 units compared to ambient conditions $\left(\mathrm{A}-p \mathrm{CO}_{2}\right)$. High temperature $\left(T+3{ }^{\circ} \mathrm{C}\right)$ corresponded to a temperature increase of $3{ }^{\circ} \mathrm{C}$ compared to ambient conditions $(T)$.

\begin{tabular}{llll}
\hline & $p \mathrm{CO}_{2}$ & Temperature & \\
\hline 1 (control) & Ambient $\left(\mathrm{A}-p \mathrm{CO}_{2}\right)$ & Ambient $(T)$ & $\mathrm{A}-p \mathrm{CO}_{2} ; T$ \\
2 & High $\left(\mathrm{H}-p \mathrm{CO}_{2}\right)$ & Ambient $(T)$ & $\mathrm{H}-p \mathrm{CO}_{2} ; T$ \\
3 & Ambient $\left(\mathrm{A}-p \mathrm{CO}_{2}\right)$ & High $\left(T+3{ }^{\circ} \mathrm{C}\right)$ & $\mathrm{A}-p \mathrm{CO}_{2} ; T+3{ }^{\circ} \mathrm{C}$ \\
4 & High $\left(\mathrm{H}-p \mathrm{CO}_{2}\right)$ & High $\left(T+3{ }^{\circ} \mathrm{C}\right)$ & $\mathrm{H}-p \mathrm{CO}_{2} ; T+3{ }^{\circ} \mathrm{C}$ \\
\hline
\end{tabular}

$15 \mathrm{~L}$ aquaria. Each assemblage was composed of $45 \mathrm{~g}$ of living $L$. corallioides thalli, $20 \mathrm{~g}$ dead $L$. corallioides thalli, two G. magus individuals, two P. miliaris individuals, and four J. exasperatus individuals, according to the proportions observed on maerl beds.

Algae and grazers were acclimated to laboratory conditions for 7 days. Then, the $\mathrm{pH}$ was gradually decreased by 0.05 units per day over 7 days and temperature increased by $0.5^{\circ} \mathrm{C}$ per day. The $\mathrm{pH}$ was controlled by modifying $p \mathrm{CO}_{2}$ through $\mathrm{CO}_{2}$ bubbling. At each season, two $p \mathrm{CO}_{2}$ conditions were tested, each with two temperature conditions to examine the interaction between $p \mathrm{CO}_{2}$ and temperature. These four conditions are presented in Table 1 .

Ambient $p \mathrm{CO}_{2}$ conditions (A- $p \mathrm{CO}_{2}$ ) were determined according to in situ winter (7.98) and summer (8.06) mean $\mathrm{pH}_{\mathrm{T}}$ ( $\mathrm{pH}$ on the total scale) monitored above maerl beds in the Bay of Brest (data from Martin, unpublished). High $p \mathrm{CO}_{2}$ $\left(\mathrm{H}-p \mathrm{CO}_{2}\right)$ corresponded to the "business-as-usual" scenario predicted for the end of the century, with a $\mathrm{pH}$ decrease of -0.33 units (RCP8.5; Bopp et al., 2013). Ambient temperature $(T)$ corresponded to in situ winter $\left(10.0^{\circ} \mathrm{C}\right)$ and summer $\left(17.1^{\circ} \mathrm{C}\right)$ conditions in the Bay of Brest recorded by SOMLIT (from 2003 to 2014), and high temperature $\left(T+3{ }^{\circ} \mathrm{C}\right)$ was determined according to the business-as-usual scenario predicted for 2100 (Bopp et al., 2013).

The $\mathrm{pH}$ and the temperature were controlled in four $100 \mathrm{~L}$ tanks, continuously supplied with filtered $(5 \mu \mathrm{m})$ natural seawater, with a high water flow rate of $150 \mathrm{~L} \mathrm{~h}^{-1}$ per tank. They were maintained by an offline feedback system (IKS Aquastar, Karlsbad, Germany) that activated or stopped heaters and solenoid valves, controlling temperature and $\mathrm{CO}_{2}$ (Air Liquide, France) bubbling in the tanks, respectively. Each $100 \mathrm{~L}$ tank provided seawater to five $15 \mathrm{~L}$ aquaria for each of the four conditions using pumps. The water flow rate was $15 \mathrm{~L} \mathrm{~h}^{-1}$ in each aquarium. Temperature was maintained constant in aquaria with water baths. Seawater $\mathrm{pH}\left(\mathrm{pH}_{\mathrm{T}}\right.$, expressed on the total hydrogen ion concentration scale; Dickson et al., 2007) and temperature were monitored every 2 days in the 20 aquaria, at different times of the day (Table 2). Seawater $\mathrm{pH}_{\mathrm{T}}$ and temperature measurements were carried out using a $\mathrm{pH}$ probe associated with a temperature sensor (PHC101, Hach Lange, IntelliCAL). The $\mathrm{pH}$ probe was calibrated using Tris / $\mathrm{HCl}$ and 2-aminopyridine / $\mathrm{HCl}$ buffers
(Dickson et al., 2007). The $\mathrm{pH}$ values of the offline feedback system were adjusted from measurements of $\mathrm{pH}_{\mathrm{T}}$ carried out every 2 days in each aquarium. Total alkalinity $\left(A_{\mathrm{T}}\right)$ was also monitored during the experiment in each aquarium at different times of the day (Table 2). For $A_{\mathrm{T}}$ analyses, seawater samples $(60 \mathrm{~mL})$ were filtered through $0.7 \mu \mathrm{m}$ Whatman GF/F filters and immediately poisoned with a mercuric chloride solution to prevent further biological activity (Dickson et al., 2007). $A_{\mathrm{T}}$ was determined using open-cell titration on an automatic titrator (TitroLine alpha, Schott SI Analytics, Mainz, Germany) according to the method developed by Dickson et al. (2007). $A_{\mathrm{T}}$ was calculated using a Gran function applied to $\mathrm{pH}$ values ranging from 3.5 to 3.0 (Dickson et al., 2007) and corrected using standard reference material provided by the Andrew G. Dickson laboratory (CRM Batch 111, accuracy of $\pm 6 \mu \mathrm{mol} \mathrm{kg}^{-1}$ ). Salinity was measured every 2 weeks with a conductivity probe (CDC401, Hach Lange, IntelliCAL, accuracy of 0.1) and remained constant during experiments $(35.2 \pm 0.2)$. From $A_{\mathrm{T}}$ and $\mathrm{pH}_{\mathrm{T}}$ measurements, dissolved inorganic carbon (DIC), saturation state of seawater with respect to aragonite $\left(\Omega_{\mathrm{Ar}}\right)$, and saturation state of seawater with respect to calcite $\left(\Omega_{\mathrm{Ca}}\right)$ were calculated with the CO2SYS software (Table 2). Mean temperature and parameters of the carbonate chemistry are given in Table 2.

Irradiance was set to the mean in situ daily irradiance at $5 \mathrm{~m}$ depth in the Bay of Brest according to Martin et al. (2006a): $30-40 \mu \mathrm{mol}$ photons $\mathrm{m}^{-2} \mathrm{~s}^{-1}$ in winter and 90$100 \mu \mathrm{mol}$ photons $\mathrm{m}^{-2} \mathrm{~s}^{-1}$ in summer. The light was provided by two or four $80 \mathrm{~W}$ fluorescent tubes (JBL Solar Ultra Marin Day, JBL Aquaria, Nelson, New Zealand) above the aquaria under a $10 / 14$ or $14 / 10 \mathrm{~h}$ light/dark photoperiod for winter or summer conditions, respectively.

\subsection{Metabolic measurements}

After 3 months in experimental conditions, metabolic measurements were performed at the species and assemblage level using incubations in acrylic respirometry chambers (Engineering and Design Plastics Ltd, Cambridge, UK). For species-scale measurements, each species was incubated separately. Community-scale measurements were performed on assemblages, incubating all individuals from all species present in each aquarium. The chamber volume was adapted 
Table 2. Physicochemical parameters (mean $\pm \mathrm{SE}$ ) of seawater in each experimental condition $\left(\mathrm{A}-p \mathrm{CO}_{2}\right.$ is ambient $p \mathrm{CO}_{2} ; \mathrm{H}-p \mathrm{CO}_{2}$ is high $p \mathrm{CO}_{2} ; T$ is ambient temperature; $T+3{ }^{\circ} \mathrm{C}$ is high temperature) in the winter and the summer. $\mathrm{pH}_{\mathrm{T}}$ and temperature were monitored every 2 days in each aquarium $(n=35)$. Total alkalinity values $\left(A_{\mathrm{T}}\right)$ are means $( \pm \mathrm{SE})$ of 28 samples measured in each aquarium. The $\mathrm{CO}_{2}$ partial pressure $\left(p \mathrm{CO}_{2}\right)$, dissolved inorganic carbon (DIC), and saturation states of seawater with respect to aragonite $\left(\Omega_{\mathrm{Ar}}\right)$ and calcite $\left(\Omega_{\mathrm{Ca}}\right)$ were calculated from $\mathrm{pH}_{\mathrm{T}}$, temperature, salinity, and $A_{\mathrm{T}}$ using CO2SYS.

\begin{tabular}{|c|c|c|c|c|c|c|c|c|}
\hline & $\begin{array}{l}\text { Experimental } \\
\text { condition }\end{array}$ & $\begin{array}{r}p \mathrm{CO}_{2} r \\
(\mu \text { atm })\end{array}$ & $\mathrm{pH}_{\mathrm{T}}$ & $\begin{array}{r}\text { Temperature } \\
\left({ }^{\circ} \mathrm{C}\right)\end{array}$ & $\begin{array}{r}A_{\mathrm{T}} \\
\left(\mu \mathrm{mol} \mathrm{kg}{ }^{-1}\right)\end{array}$ & $\begin{array}{r}\text { DIC } \\
\left(\mu \mathrm{mol} \mathrm{kg}{ }^{-1}\right)\end{array}$ & $\Omega_{\mathrm{Ar}}$ & $\Omega_{\mathrm{Ca}}$ \\
\hline \multirow{4}{*}{ Winter } & A- $p \mathrm{CO}_{2} ; T$ & $490( \pm 5)$ & $7.97( \pm 0.04)$ & $10.1( \pm 0.3)$ & $2348( \pm 6)$ & $2189( \pm 6)$ & $1.84( \pm 0.02)$ & $2.89( \pm 0.02)$ \\
\hline & H- $p \mathrm{CO}_{2} ; T$ & $1183( \pm 10)$ & $7.63( \pm 0.03)$ & $10.1( \pm 0.3)$ & $2342( \pm 7)$ & $2306( \pm 7)$ & $0.89( \pm 0.01)$ & $1.40( \pm 0.01)$ \\
\hline & $\mathrm{A}-p \mathrm{CO}_{2} ; T+3{ }^{\circ} \mathrm{C}$ & $513( \pm 5)$ & $7.97( \pm 0.03)$ & $13.7( \pm 0.1)$ & $2341( \pm 5)$ & $2166( \pm 5)$ & $2.01( \pm 0.01)$ & $3.14( \pm 0.02)$ \\
\hline & $\mathrm{H}-p \mathrm{CO}_{2} ; T+3{ }^{\circ} \mathrm{C}$ & $1087( \pm 18)$ & $7.64( \pm 0.03)$ & $13.6( \pm 0.2)$ & $2329( \pm 2)$ & $2266( \pm 4)$ & $1.09( \pm 0.01)$ & $1.70( \pm 0.02)$ \\
\hline \multirow{4}{*}{ Summer } & A- $p \mathrm{CO}_{2} ; T$ & $426( \pm 4)$ & $8.03( \pm 0.04)$ & $17.1( \pm 0.2)$ & $2359( \pm 3)$ & $2127( \pm 3)$ & $2.60( \pm 0.02)$ & $4.03( \pm 0.03)$ \\
\hline & H- $p \mathrm{CO}_{2} ; T$ & $948( \pm 9)$ & $7.72( \pm 0.03)$ & $17.1( \pm 0.2)$ & $2382( \pm 4)$ & $2279( \pm 4)$ & $1.45( \pm 0.01)$ & $2.24( \pm 0.02)$ \\
\hline & A- $p \mathrm{CO}_{2} ; T+3{ }^{\circ} \mathrm{C}$ & $432( \pm 4)$ & $8.01( \pm 0.04)$ & $20.0( \pm 0.5)$ & $2364( \pm 3)$ & $2109( \pm 3)$ & $2.88( \pm 0.02)$ & $4.43( \pm 0.03)$ \\
\hline & $\mathrm{H}-p \mathrm{CO}_{2} ; T+3{ }^{\circ} \mathrm{C}$ & $879( \pm 7)$ & $7.74( \pm 0.02)$ & $20.2( \pm 0.3)$ & $2369( \pm 2)$ & $2238( \pm 2)$ & $1.71( \pm 0.01)$ & $2.64( \pm 0.02)$ \\
\hline
\end{tabular}

to species size. It was $80 \mathrm{~mL}$ for J. exasperatus and epiphytes, $185 \mathrm{~mL}$ for P. miliaris, G. magus and living and dead $L$. corallioides, and $600 \mathrm{~mL}$ for the assemblages. After assemblage incubations, epiphytic algae that spontaneously grew on $L$. corallioides during the experiments were carefully removed and incubated separately. Metabolic measurements (net photosynthetic and respiration rates) for the main epiphytic algae Rhodymenia ardissonei and Solieria chordalis were only examined in the summer, when their biomass was sufficient for measurements. Species were placed on a plastic grid above a stir bar in the chambers to ensure the seawater was well mixed. For G. magus and P. miliaris, net calcification, respiration, and excretion (ammonia release) rates were measured. For $J$. exasperatus, only respiration rates were measured due to its limited size and metabolic rates. For grazers, physiological rates were measured under ambient irradiance. For each grazer species, individuals present in each aquarium were incubated together. For living and dead L. corallioides and assemblages, net photosynthetic and light calcification rates were measured under ambient irradiance, and respiration and dark calcification rates were measured in the dark. For light incubations, chambers were placed inside aquaria to control temperature. For dark incubations, chambers were placed in a plastic crate filled with aquaria seawater in an open circuit to keep the temperature constant. Incubation duration was adjusted to keep oxygen saturation above $80 \%$. Incubations lasted approximately from $1 \mathrm{~h}$ for $G$. $m a-$ gus to $2.5 \mathrm{~h}$ for dead maerl. For assemblages, the metabolism was measured from the incubations of all species together.

Oxygen concentrations were measured at the beginning and at the end of each incubation, using an optical fibre system (FIBOX 3, PreSens, Regensburg, Germany). Reactive spots were calibrated with 0 and $100 \%$ buffer solutions. The $0 \%$ buffer solution was prepared by dissolving $1 \mathrm{~g}$ of sodium sulfite $\left(\mathrm{Na}_{2} \mathrm{SO}_{3}\right)$ in $100 \mathrm{~mL}$ of seawater. The $100 \%$ buffer solution was prepared by bubbling air into $100 \mathrm{~mL}$ of seawater using an air pump for $20 \mathrm{~min}$ to obtain air-saturated seawa- ter. Net primary production (NPP, $\mu \mathrm{mol} \mathrm{O}_{2} \mathrm{~g} \mathrm{DW}^{-1} \mathrm{~h}^{-1}$ ) or respiration $\left(R, \mu \mathrm{mol} \mathrm{O}_{2} \mathrm{~g} \mathrm{DW}^{-1} \mathrm{~h}^{-1}\right)$ rates were calculated following Eq. (1):

$\mathrm{NPP}$ or $R=\frac{\Delta \mathrm{O}_{2} \times V}{\Delta t \times \mathrm{DW}}$,

where $\Delta \mathrm{O}_{2}$ is the difference between the initial and final oxygen concentrations $\left(\mu \mathrm{mol} \mathrm{O}_{2} \mathrm{~L}^{-1}\right), V$ the volume of the chamber (L), $\Delta \mathrm{t}$ the incubation time (h), and DW the dry weight of the species incubated $(\mathrm{g})$. The dry weight was obtained after $48 \mathrm{~h}$ at $60^{\circ} \mathrm{C}$. For gastropods, the body was separated from the shell to consider the dry weight of the body only.

For algae and the assemblages, gross primary production (GPP) was calculated following Eq. (2):

$\mathrm{GPP}=\mathrm{NPP}-R$.

Control incubations containing only seawater were carried out to correct for oxygen fluxes due to any additional biological activity in seawater. Oxygen fluxes calculated in control chambers were subtracted from oxygen fluxes of chambers containing species.

Seawater samples were taken in the aquaria at the beginning of the incubation and in the chambers at the end of the incubations (except for fleshy algae and J. exasperatus) to measure ammonium $\left(\mathrm{NH}_{4}^{+}\right)$concentration and total alkalinity $\left(A_{\mathrm{T}}\right)$. To do so, $45 \mathrm{~mL}$ seawater samples for $\mathrm{NH}_{4}^{+}$analyses were fixed with reagent solutions and stored in the dark. $\mathrm{NH}_{4}^{+}$concentrations were determined according to the Solorzano method (Solorzano, 1969). Absorbance was measured by spectrophotometry at a wavelength of $630 \mathrm{~nm}$ (spectrophotometer UV-1201 V, Shimadzu Corp, Kyoto, Japan). For grazers, ammonia excretion rates $(E, \mu \mathrm{mol}$ $\mathrm{NH}_{4}^{+} \mathrm{g} \mathrm{DW}^{-1} \mathrm{~h}^{-1}$ ) were calculated following Eq. (3):

$E=\frac{\Delta \mathrm{NH}_{4}^{+} \times V}{\Delta t \times \mathrm{DW}}$, 
where $\Delta \mathrm{NH}_{4}^{+}$is the difference between the initial and final ammonium concentrations $\left(\mu \mathrm{mol} \mathrm{NH} \mathrm{H}_{4}^{+} \mathrm{g} \mathrm{DW}^{-1} \mathrm{~h}^{-1}\right)$.

For $A_{\mathrm{T}}$ analyses, $60 \mathrm{~mL}$ seawater samples were filtered through $0.7 \mu \mathrm{m}$ Whatman GF/F filters and were immediately poisoned with a mercuric chloride solution. Total alkalinity was determined according to the method described above. Net calcification rates at light and in the dark $\left(G_{1}\right.$ and $G_{\mathrm{d}}$, respectively; in $\mu \mathrm{mol} \mathrm{CaCO}_{3} \mathrm{~g} \mathrm{DW}^{-1} \mathrm{~h}^{-1}$ ) were calculated according to the alkalinity anomaly technique (Smith and Key, 1975) and corrected for $\mathrm{NH}_{4}^{+}$fluxes (Gazeau et al., 2015). This correction was applied to calcareous species and assemblage incubations following Eq. (4):

$G_{1}$ or $G_{\mathrm{d}}=\frac{\left(-\Delta A_{\mathrm{T}}+\Delta \mathrm{NH}_{4}{ }^{+}\right) \times V}{2 \times \Delta t \times \mathrm{DW}}$,

where $G_{1}$ is the net calcification in the light, $G_{\mathrm{d}}$ is the net calcification in the dark, and $\Delta A_{\mathrm{T}}$ is the difference between the initial and final $A_{\mathrm{T}}\left(\mu \mathrm{eq} \mathrm{L}^{-1}\right)$.

After the 3-month experiments, epiphytic algae that spontaneously grew on $L$. corallioides during experiments were picked off and dried at $60^{\circ} \mathrm{C}$ for $48 \mathrm{~h}$ to determine their dry weight.

\subsection{Chlorophyll $a$ analysis}

At the end of the experiments, thalli of living and dead $L$. corallioides were collected in each aquarium and immediately frozen at $-20^{\circ} \mathrm{C}$ pending analyses. In dead maerl, chlorophyll $a$ content was measured in order to check for the presence of associated microflora and potential subsequent metabolism. Then samples were freeze-dried and crushed into a powder using a mortar, in the dark. An aliquot of $0.15 \mathrm{~g}$ of powder was precisely weighed and suspended in $10 \mathrm{~mL}$ of $90 \%$ acetone and stored in the dark at $4{ }^{\circ} \mathrm{C}$ for $12 \mathrm{~h}$. Samples were then centrifuged at $4000 \mathrm{rpm}$. The supernatant was collected and absorbance was measured at $630\left(A_{630}\right)$, $647\left(A_{647}\right), 664\left(A_{664}\right)$, and $691\left(A_{691}\right) \mathrm{nm}$. Chlorophyll $a$ $\left(\mathrm{Chl} a\right.$ ) concentrations $\left(\mu \mathrm{g} \mathrm{g} \mathrm{DW}{ }^{-1}\right)$ were calculated from Ritchie (2008) following Eq. (5):

Chl $a=$

$\frac{\left(-0.3319 A_{630}-1.7485 A_{647}+11.9442 A_{664}-1.4306 A_{691}\right) \times V}{\mathrm{mp}}$,

where $V$ is the volume of acetone $(\mathrm{mL})$ and $\mathrm{mp}$ the mass of powder $(\mathrm{g})$.

\subsection{Data analysis}

Comparisons in species and assemblage physiological rates between the winter and summer seasons was performed using $t$ tests, after checking the normality and homogeneity of variances. The influence of temperature and $p \mathrm{CO}_{2}$ was tested on metabolic rates of grazers (P. miliaris, G. magus, and $J$. exasperatus), living and dead maerl, epiphytic biomass and assemblages. Normality of the data and variance homogeneity were checked for all variables. When assumptions were respected, two-way ANOVA were performed, using temperature and $p \mathrm{CO}_{2}$ as fixed orthogonal factors. When assumptions were not respected, two-way nonparametric ScheirerRay-Hare tests were run. Statistical analyses were conducted separately for winter and summer experiments in order to keep a balanced design. When two-way AVOVAs showed significant results, post hoc tests (Tukey honest significant difference, HSD) were performed to compare the four treatments.

The effects of $p \mathrm{CO}_{2}$ and temperature on the physiological rates of the epiphytic algae $R$. ardissone $i$ and $S$. chordalis were only tested in the summer. Statistical analyses were carried out using the statistical package $\mathrm{R}$, version 3.2.2.

\section{Results}

\subsection{Metabolic responses of grazers to acidification and warming}

In the urchin P. miliaris and the gastropod G. magus, the metabolism was significantly higher in the summer than in the winter, except for $P$. miliaris $R$, for which no difference was detected (Table 3 ). In the gastropod J. exasperatus, $R$ did not vary with the season. High temperature $\left(+3^{\circ} \mathrm{C}\right)$ reduced $P$. miliaris $R$ in the summer, while $p \mathrm{CO}_{2}$ had no significant effect on P. miliaris $R$ (Fig. 1a; Table 4). P. miliaris $G_{1}$ was significantly affected by the interaction between temperature and $p \mathrm{CO}_{2}$ in the summer (Figs. $1 \mathrm{~b}, \mathrm{~S} 1 \mathrm{~b}$ ), which negated the positive effect of increased temperature or $p \mathrm{CO}_{2}$ alone. $P$. miliaris $E$ was higher under control conditions in the summer and significantly lower under increased temperature (Table 4; Fig. 1c). G. magus $R$ was lower under high $p \mathrm{CO}_{2}$ in the winter only (Table 4; Fig. 1d). Neither temperature nor $p \mathrm{CO}_{2}$ increases significantly affected $G$. magus $G_{1}$ and $E$ (Table 4; Fig. 1e-f). In J. exasperatus, $R$ increased under elevated temperature but in winter conditions only (Table 4; Fig. 1g). J. exasperatus $R$ was negatively influenced by the $p \mathrm{CO}_{2}$ increase in the winter but positively in the summer.

\subsection{Metabolic responses of living $L$. corallioides to acidification and warming}

The metabolism of living $L$. corallioides was higher in the summer than in the winter, except for NPP (Table 3). Living maerl NPP did not differ among temperature and $p \mathrm{CO}_{2}$ conditions regardless of the season, while GPP was lower under high temperature in the winter (Table 5; Fig. 2a, b). $R$ was significantly reduced by the high temperature condition in the winter, whereas an increase in $R$ was observed in the summer (Table 5; Fig. 2c). No effect of season was observed on chlorophyll $a$ content (Tables 3,6). Chlorophyll $a$ content was reduced by the high temperature condition in the winter only (Table 5). The $G_{1}$ of living maerl was not significantly influenced by increased temperature and $p \mathrm{CO}_{2}$, regardless of the season (Table 5; Fig. 2d). Conversely, in- 


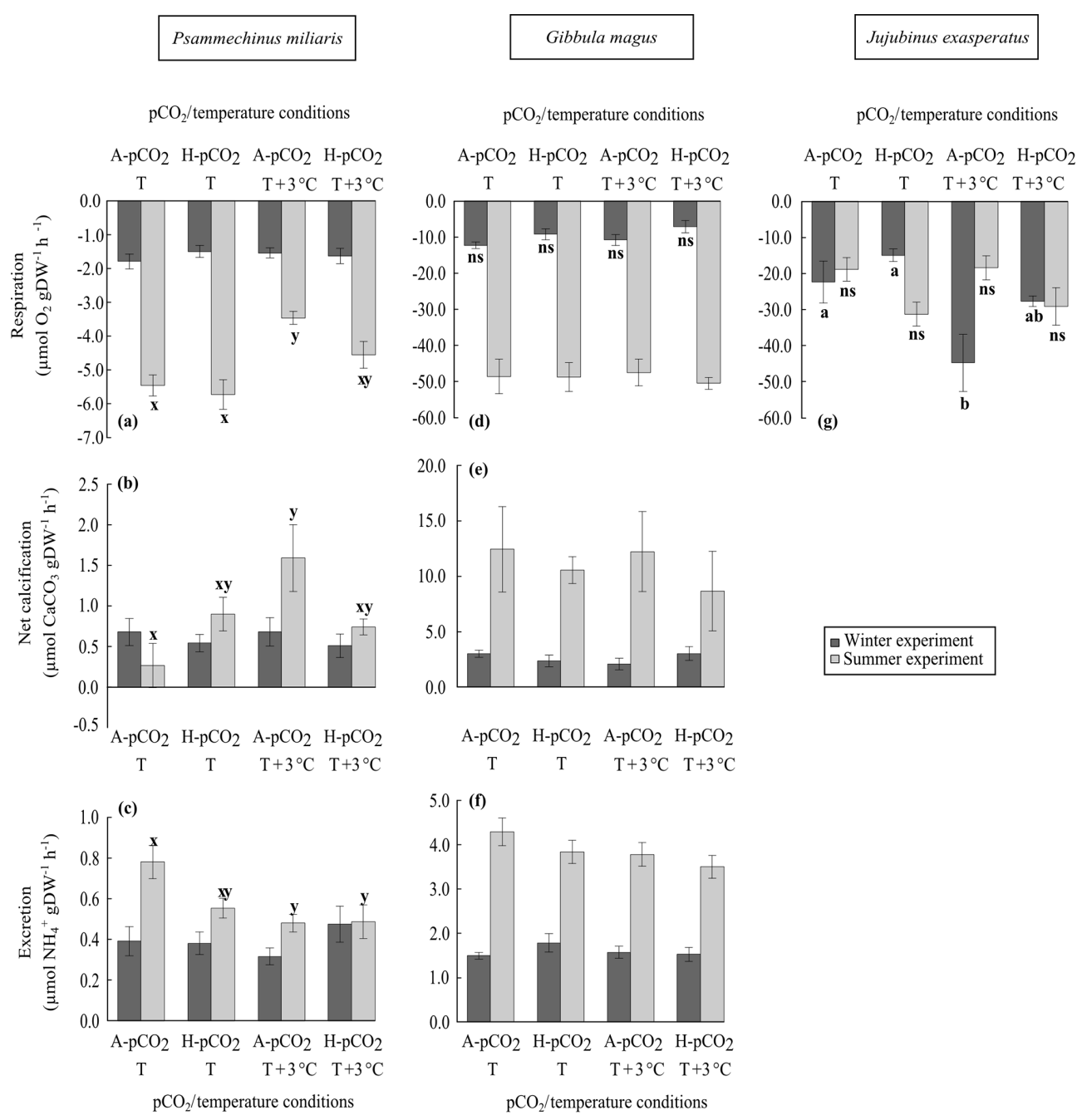

Figure 1. Respiration, net calcification, and excretion rates (mean $\pm \mathrm{SE}, n=5)$ of the grazers P. miliaris (a-c) and G. magus (d-f) and respiration of $J$. exasperatus $(\mathrm{g})$ in the different $p \mathrm{CO}_{2}\left(\mathrm{~A}-p \mathrm{CO}_{2}\right.$ is ambient $p \mathrm{CO}_{2} ; \mathrm{H}-p \mathrm{CO}_{2}$ is high- $\left.p C \mathrm{O}_{2}\right)$ and temperature $(T$ is ambient temperature; $T+3{ }^{\circ} \mathrm{C}$ is high temperature) conditions. The species were maintained in assemblages for 3 months in winter (dark gray) and summer conditions (light gray). Different letters show significant differences (Tukey HSD test) between the four treatments in the winter (letters $\mathrm{a}$ and $\mathrm{b}$ ) and summer (letters $\mathrm{x}$ and $\mathrm{y}$ ). ns is not significant. Tukey tests were performed when a significant effect of temperature or $p \mathrm{CO}_{2}$ was detected using two-way ANOVAs.

creased temperature enhanced $G_{\mathrm{d}}$ in the winter, but no effect was detected in the summer (Fig. 2e). A significant decline in $G_{\mathrm{d}}$ occurred under high $p \mathrm{CO}_{2}$ regardless of the season. Net dissolution, because $G_{\mathrm{d}}$ was negative, was recorded in the winter under high $p \mathrm{CO}_{2}$ conditions. This negative effect of increased $p \mathrm{CO}_{2}$ was alleviated under elevated temperature.

\subsection{Metabolic responses of dead $L$. corallioides to acidification and warming}

In dead $L$. corallioides, NPP, GPP, $R$, and $G_{1}$ were significantly higher in the summer, while no effect of season was observed on $G_{\mathrm{d}}$ (Table 3 ). The high temperature condition $\left(+3^{\circ} \mathrm{C}\right.$ ) did not affect dead maerl NPP, GPP, or $R$ (Table 5; Fig. 2f-h). The $p \mathrm{CO}_{2}$ increase did not affect dead maerl
NPP and GPP in either season. However, a decrease in $R$ was observed under high $p \mathrm{CO}_{2}$ in the summer. Chlorophyll $a$ content did not differ between seasons (Tables 3,6 ) but was significantly affected by the temperature and $p \mathrm{CO}_{2}$ interaction (Table 5; Figs. S1a, 1f). Dead maerl $G_{1}$ significantly increased under high temperature (Fig. 2i). Conversely, a negative impact of high $p \mathrm{CO}_{2}$ was on $G_{1}$ in the winter and summer. In the dark, net dissolution was observed on dead maerl regardless of the temperature and $p \mathrm{CO}_{2}$ conditions (Fig. 2j). No temperature effect was observed on dark dissolution. However, dark dissolution rates were significantly higher under high $p \mathrm{CO}_{2}$ treatments, regardless of the season. 
Living $L$. corallioides
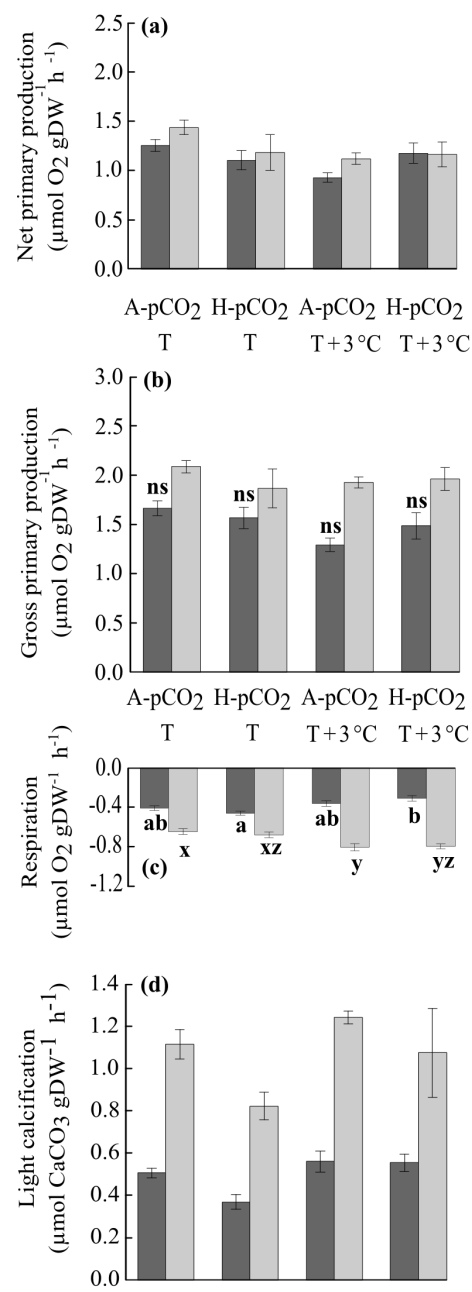

A-pCO 2 H-pCO 2 A-pCO 2 H-pCO 2

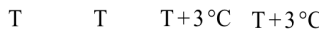

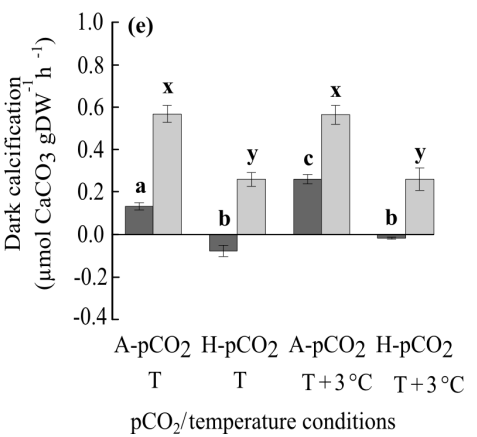

Dead L. corallioides

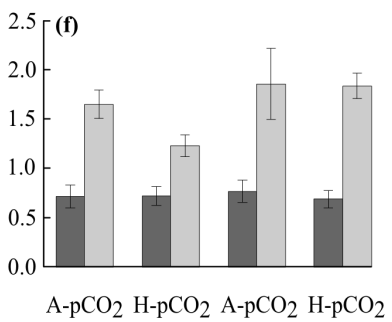

$\begin{array}{llll}\mathrm{T} & \mathrm{T} & \mathrm{T}+3{ }^{\circ} \mathrm{C} & \mathrm{T}+3{ }^{\circ} \mathrm{C}\end{array}$

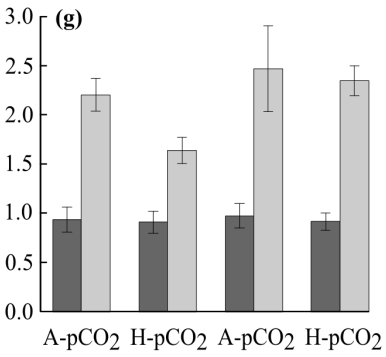

$\mathrm{T} \quad \mathrm{T} \quad \mathrm{T}+3{ }^{\circ} \mathrm{C} \quad \mathrm{T}+3{ }^{\circ} \mathrm{C}$
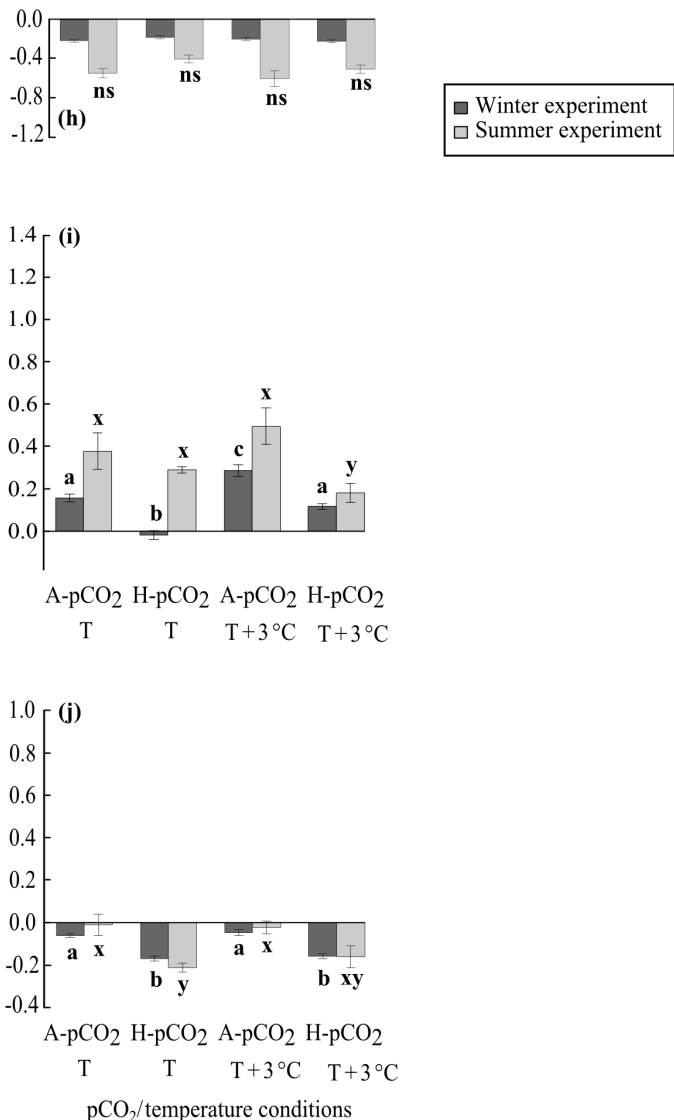

Figure 2. Net and gross primary production, respiration, and light and dark calcification rates (mean \pm SE, $n=5)$ of living $(\mathbf{a}-\mathbf{e})$ and dead thalli ( $\mathbf{f}-\mathbf{j})$ of $L$. corallioides in the different $p \mathrm{CO}_{2}\left(\mathrm{~A}-p \mathrm{CO}_{2}\right.$ is ambient $p \mathrm{CO}_{2} ; \mathrm{H}-p \mathrm{CO}_{2}$ is high- $\left.p \mathrm{CO}_{2}\right)$ and temperature $(T$ is ambient temperature; $T+3{ }^{\circ} \mathrm{C}$ is high temperature) treatments after 3 months in winter (dark gray) and summer conditions (light gray). Letters indicate significant differences between the four treatments in winter $(\mathrm{a}, \mathrm{b}, \mathrm{c})$ and summer $(\mathrm{x}, \mathrm{y}, \mathrm{z})$ conditions (Tukey HSD test). ns is not significant. Tukey tests were performed when a significant effect of temperature or $p \mathrm{CO}_{2}$ was detected using two-way ANOVAs. 

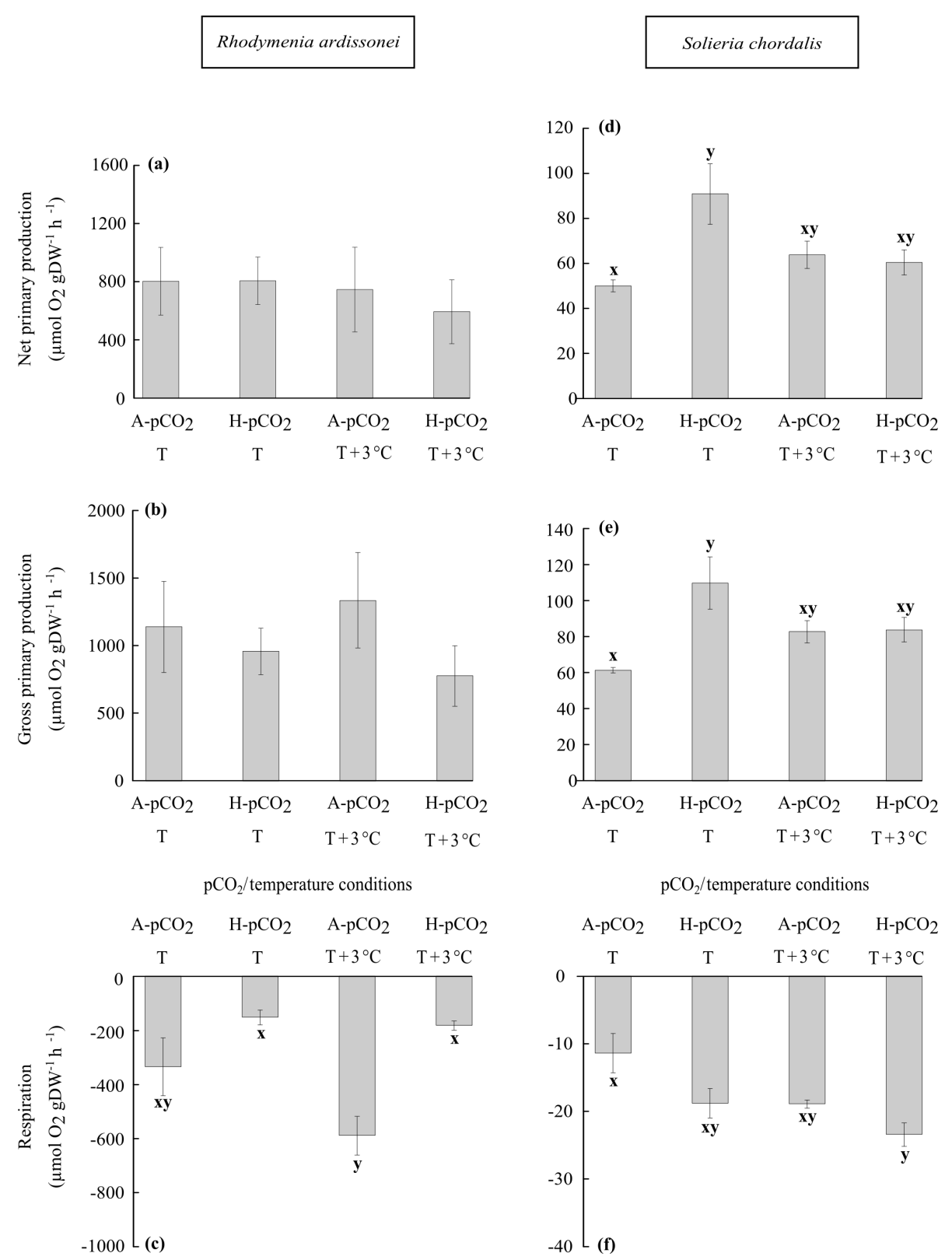

Figure 3. Summer net and gross primary production and respiration rates (mean $\pm \mathrm{SE}, n=5$ ) of the two main epiphytic fleshy algae Rhodymenia ardissonei $(\mathbf{a}-\mathbf{c})$ and Solieria chordalis $(\mathbf{d}-\mathbf{f})$, in the different $p \mathrm{CO}_{2}\left(\mathrm{~A}-p \mathrm{CO}_{2}\right.$ is ambient $p \mathrm{CO}_{2} ; \mathrm{H}-p \mathrm{CO}_{2}$ is high- $\left.p \mathrm{CO}_{2}\right)$ and temperature ( $T$ is ambient temperature; $T+3{ }^{\circ} \mathrm{C}$ is high temperature) treatments. Letters indicate significant differences between the four treatments in summer (x, y) conditions (Tukey HSD test). Tukey tests were performed when a significant effect of temperature or $p \mathrm{CO}_{2}$ was detected.

\subsection{Growth and metabolic responses of epiphytic algae to acidification and warming}

Mean GPP and R for the two epiphytic algae $R$. ardissonei and $S$. chordalis measured in the summer are presented in Fig. 3. $R$. ardissonei NPP and GPP were not affected by high temperature or $p \mathrm{CO}_{2}$ conditions, and $R$ was reduced under high $p \mathrm{CO}_{2}$ (Table 7; Fig. 3a-c). In S. chordalis, NPP and GPP were significantly affected by the interaction between temperature and $p \mathrm{CO}_{2}$ (Table 7; Figs. 3d, e; S1c, S1d). $R$ was enhanced by the high temperature and $p \mathrm{CO}_{2}$ conditions and their combination resulted in a greater $R$ (Fig. $3 \mathrm{f}$ ).

The mean biomass of epiphytic fleshy algae at the end of the experiment was significantly higher in the summer than in the winter $(+81 \%, t$ test, $p=0.045$; Fig. 4). Epiphyte biomass was not affected by increased temperature or $p \mathrm{CO}_{2}$ in the winter (two-way ANOVA, $p=0.95$ and 0.67 respectively). In the summer, increased temperature reduced epiphyte biomass under ambient $p \mathrm{CO}_{2}$ and stimulated 


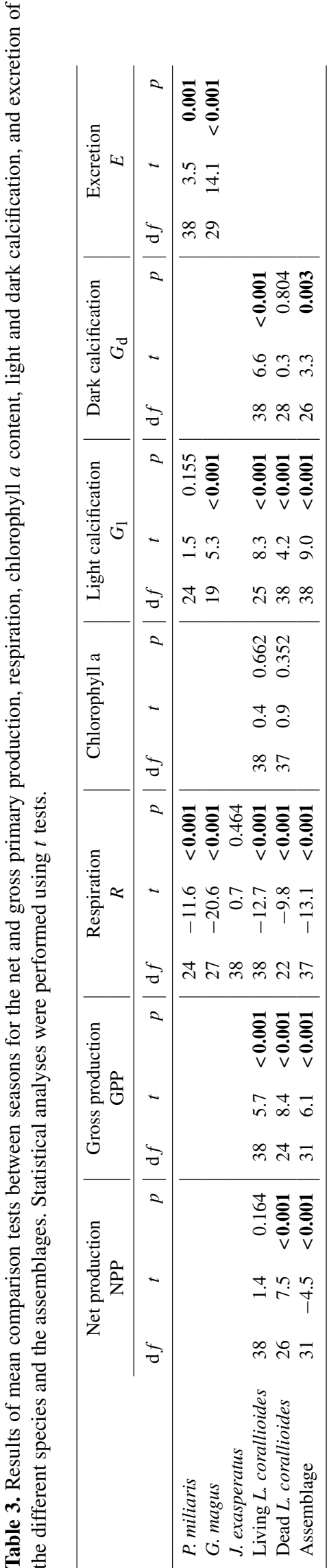

Table 4. Results the analysis of variance testing the effects of temperature $(T)$ and $p \mathrm{CO}_{2}$ on respiration, net calcification, and excretion rates in the urchin Psammechinus miliaris and the two gastropods Gibbula magus and Jujubinus exasperatus for winter and summer experiments $(n=5)$. Statistical analyses were performed using two-way crossed ANOVAs and Scheirer-Ray-Hare tests when test assumptions were not respected (in italic). Significant $p$ values are shown in bold $(\alpha=0.05)$. Degrees of freedom $=1$.

\begin{tabular}{|c|c|c|c|c|c|c|c|}
\hline & & \multicolumn{2}{|c|}{$\begin{array}{c}\text { Respiration } \\
R\end{array}$} & \multicolumn{2}{|c|}{$\begin{array}{l}\text { Net calcification } \\
G\end{array}$} & \multicolumn{2}{|c|}{$\begin{array}{c}\text { Excretion } \\
\qquad E\end{array}$} \\
\hline & & $F$ & $p$ & $F$ & $p$ & $F$ & $p$ \\
\hline \multirow{6}{*}{ 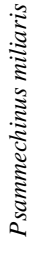 } & $\begin{array}{l}\text { Winter } \\
T\end{array}$ & 1.8 & 0.184 & 0.3 & 0.588 & 0.0 & 0.890 \\
\hline & $p \mathrm{CO}_{2}$ & 0.0 & 0.865 & 1.0 & 0.343 & 1.2 & 0.286 \\
\hline & $p \mathrm{CO}_{2} \times \mathrm{T}$ & 0.2 & 0.672 & 0.2 & 0.640 & 1.6 & 0.222 \\
\hline & $\begin{array}{l}\text { Summer } \\
T\end{array}$ & 20.8 & $<0.001 \backslash$ & 4.8 & 0.045 & 7.6 & $0.014 \backslash$ \\
\hline & $p \mathrm{CO}_{2}$ & 3.9 & 0.066 & 0.1 & 0.823 & 2.7 & 0.119 \\
\hline & $p \mathrm{CO}_{2} \times T$ & 1.4 & 0.252 & 6.6 & 0.022 & 3.1 & 0.098 \\
\hline \multirow{7}{*}{ 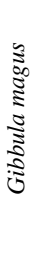 } & Winter & & & & & & \\
\hline & $T$ & 1.1 & 0.303 & 0.0 & $\begin{array}{l}0.895 \\
0.787\end{array}$ & 0.4 & 0.550 \\
\hline & $\begin{array}{l}p \mathrm{CO}_{2} \\
p \mathrm{CO}_{2} \times T\end{array}$ & $\begin{array}{l}4.8 \\
0.0\end{array}$ & $\begin{array}{r}\mathbf{0 . 0 4 3} \searrow \\
0.876\end{array}$ & $\begin{array}{l}0.1 \\
3.9\end{array}$ & $\begin{array}{l}0.787 \\
0.065\end{array}$ & $\begin{array}{l}0.6 \\
1.3\end{array}$ & $\begin{array}{l}0.435 \\
0.281\end{array}$ \\
\hline & Summer & & & & & & \\
\hline & $T$ & 0.0 & 0.932 & 0.8 & 0.381 & 2.4 & 0.145 \\
\hline & $p \mathrm{CO}_{2}$ & 0.2 & 0.679 & 0.6 & 0.449 & 1.8 & 0.199 \\
\hline & $p \mathrm{CO}_{2} \times T$ & 0.1 & 0.717 & 0.4 & 0.546 & 0.1 & 0.749 \\
\hline \multirow{8}{*}{ 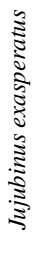 } & Winter & & & & & & \\
\hline & $T$ & 8.6 & $0.010 \nearrow$ & & & & \\
\hline & $p \mathrm{CO}_{2}$ & 5.6 & $0.031 \searrow$ & & & & \\
\hline & $p \mathrm{CO}_{2} \times T$ & 0.8 & 0.391 & & & & \\
\hline & Summer & & & & & & \\
\hline & $T$ & 0.1 & 0.750 & & & & \\
\hline & $p \mathrm{CO}_{2}$ & 8.9 & $0.009 \nearrow$ & & & & \\
\hline & $p \mathrm{CO}_{2} \times T$ & 0.8 & 0.832 & & & & \\
\hline
\end{tabular}

epiphyte biomass under elevated $p \mathrm{CO}_{2}$ (two-way ANOVA, $p=0.013$; Fig. S1e).

\subsection{Metabolic responses of assemblages to acidification and warming}

Assemblage metabolism was significantly higher in the summer than in the winter regardless of the metabolic parameter tested (Table 3). No temperature effect was observed on NPP, GPP, and $R$ in either season (Table 8; Fig. 5a-c). The high $p \mathrm{CO}_{2}$ condition enhanced NPP in both seasons. High $p \mathrm{CO}_{2}$ increased GPP in the summer only. Similarly, $R$ significantly increased under high $p \mathrm{CO}_{2}$ in summer conditions. $G_{1}$ increased under high temperature in the summer only (Fig. 5d). Conversely, high $p \mathrm{CO}_{2}$ reduced $G_{1}$ regardless of the season. In the dark, net dissolution was observed in the winter, but net precipitation occurred in summer conditions at high temperature (Fig. 5e). In the winter, high $p \mathrm{CO}_{2}$ increased net dissolutions rates, while in the summer $G_{\mathrm{d}}$ increased under elevated temperature. 
Table 5. Results the analysis of variance for the effects of temperature $(T)$ and $p \mathrm{CO}_{2}$ on net and gross primary production, respiration, chlorophyll $a$ content, and light and dark calcification rates of living and dead Lithothamnion corallioides $(n=5)$. Statistical analyses were performed using two-way crossed ANOVAs and Scheirer-Ray-Hare tests when test assumptions were not respected (in italic). Significant $p$ values are shown in bold $(\alpha=0.05)$. Degrees of freedom $=1$.

\begin{tabular}{|c|c|c|c|c|c|c|c|c|c|c|c|c|c|}
\hline & & \multicolumn{2}{|c|}{$\begin{array}{l}\text { Net production } \\
\text { NPP }\end{array}$} & \multicolumn{2}{|c|}{$\begin{array}{l}\text { Gross production } \\
\text { GPP }\end{array}$} & \multicolumn{2}{|c|}{$\begin{array}{c}\text { Respiration } \\
\quad R \\
\end{array}$} & \multicolumn{2}{|c|}{ Chlorophyll $a$} & \multicolumn{2}{|c|}{$\begin{array}{l}\text { Light calcification } \\
\qquad G_{1}\end{array}$} & \multicolumn{2}{|c|}{$\begin{array}{c}\text { Dark calcification } \\
G_{\mathrm{d}} \\
\end{array}$} \\
\hline & & $F$ & $p$ & $F$ & $p$ & $F$ & $p$ & $F$ & $p$ & $F$ & $p$ & $F$ & $p$ \\
\hline 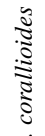 & $\begin{array}{l}\text { Winter } \\
T \\
p \mathrm{CO}_{2} \\
p \mathrm{CO}_{2} \times T\end{array}$ & $\begin{array}{l}4.4 \\
0.6 \\
3.2 \\
\end{array}$ & $\begin{array}{l}0.052 \\
0.438 \\
0.092\end{array}$ & $\begin{array}{l}8.0 \\
0.6 \\
1.0\end{array}$ & $\begin{array}{r}\mathbf{0 . 0 1 2} \searrow \\
0.444 \\
0.329\end{array}$ & $\begin{array}{r}13.1 \\
0.1 \\
3.8\end{array}$ & $\begin{array}{r}\mathbf{0 . 0 0 2} \searrow \\
0.733 \\
0.070\end{array}$ & $\begin{array}{l}5.9 \\
1.6 \\
0.0\end{array}$ & $\begin{array}{r}\mathbf{0 . 0 2 7} \backslash \\
0.227 \\
0.888\end{array}$ & $\begin{array}{l}3.6 \\
3.2 \\
0.8\end{array}$ & & $\begin{array}{r}10.0 \\
153.3 \\
3.6\end{array}$ & $\begin{array}{r}\mathbf{0 . 0 0 6} \nearrow \\
<\mathbf{0 . 0 0 1} \searrow \\
0.075\end{array}$ \\
\hline 光 & $\begin{array}{l}\text { Summer } \\
T \\
p \mathrm{CO}_{2} \\
p \mathrm{CO}_{2} \times T\end{array}$ & $\begin{array}{l}2.0 \\
0.8 \\
1.5\end{array}$ & $\begin{array}{l}0.182 \\
0.399 \\
0.240\end{array}$ & $\begin{array}{l}1.9 \\
0.4 \\
0.7\end{array}$ & $\begin{array}{l}0.174 \\
0.545 \\
0.406\end{array}$ & $\begin{array}{r}20.9 \\
0.2 \\
0.4\end{array}$ & $\begin{array}{r}<\mathbf{0 . 0 0 1} \nearrow \\
0.701 \\
0.515\end{array}$ & $\begin{array}{l}1.5 \\
0.7 \\
0.6\end{array}$ & $\begin{array}{l}0.226 \\
0.406 \\
0.450\end{array}$ & $\begin{array}{l}3.3 \\
3.6 \\
0.2\end{array}$ & $\begin{array}{l}0.070 \\
0.059 \\
0.650\end{array}$ & $\begin{array}{r}0.0 \\
50.0 \\
0.0\end{array}$ & $\begin{array}{r}0.981 \\
<\mathbf{0 . 0 0 1} \searrow \\
0.956\end{array}$ \\
\hline 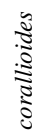 & $\begin{array}{l}\text { Winter } \\
T \\
p \mathrm{CO}_{2} \\
p \mathrm{CO}_{2} \times T\end{array}$ & $\begin{array}{l}0.0 \\
0.1 \\
0.3\end{array}$ & $\begin{array}{l}0.909 \\
0.713 \\
0.592\end{array}$ & $\begin{array}{l}0.0 \\
0.1 \\
0.0\end{array}$ & $\begin{array}{l}0.970 \\
0.764 \\
0.933\end{array}$ & $\begin{array}{l}0.0 \\
0.1 \\
0.9\end{array}$ & & $\begin{array}{l}0.0 \\
0.1 \\
6.3\end{array}$ & $\begin{array}{l}0.991 \\
0.813 \\
\mathbf{0 . 0 2 4}\end{array}$ & $\begin{array}{r}20.2 \\
61.1 \\
0.0\end{array}$ & $\begin{array}{r}<0.001 \nearrow \\
<\mathbf{0 . 0 0 1} \searrow \\
0.881 \\
\end{array}$ & $\begin{array}{r}0.1 \\
99.6 \\
0.0\end{array}$ & $\begin{array}{r}0.717 \\
<\mathbf{0 . 0 0 1} \searrow \\
0.846 \\
\end{array}$ \\
\hline 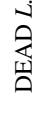 & $\begin{array}{l}\text { Summer } \\
T \\
p \mathrm{CO}_{2} \\
p \mathrm{CO}_{2} \times T\end{array}$ & $\begin{array}{l}3.7 \\
1.1 \\
0.9\end{array}$ & $\begin{array}{l}0.073 \\
0.314 \\
0.360\end{array}$ & $\begin{array}{l}3.7 \\
1.8 \\
0.8\end{array}$ & $\begin{array}{l}0.074 \\
0.197 \\
0.390\end{array}$ & $\begin{array}{l}2.0 \\
4.8 \\
0.2\end{array}$ & $\begin{array}{r}0.173 \\
\mathbf{0 . 0 4 3} \searrow \\
0.669\end{array}$ & $\begin{array}{r}0.7 \\
9.9 \\
30.3\end{array}$ & $\begin{array}{r}0.414 \\
\mathbf{0 . 0 0 6} \\
<\mathbf{0 . 0 0 1}\end{array}$ & $\begin{array}{l}0.2 \\
9.6 \\
1.9\end{array}$ & $\begin{array}{r}0.650 \\
0.002 \searrow \\
0.174\end{array}$ & $\begin{array}{r}0.2 \\
17.8 \\
0.6\end{array}$ & $\begin{array}{r}0.639 \\
<\mathbf{0 . 0 0 1} \searrow \\
0.441\end{array}$ \\
\hline
\end{tabular}

Table 6. Chlorophyll $a$ content (mean $\pm \mathrm{SE}$ ) of living and dead L. corallioides in the different $p \mathrm{CO}_{2} p \mathrm{CO}_{2}\left(\mathrm{~A}-p \mathrm{CO}_{2}\right.$ is ambient $p \mathrm{CO}_{2}$; $\mathrm{H}-p \mathrm{CO}_{2}$ is high- $p \mathrm{CO}_{2}$ ) and temperature ( $T$ is ambient temperature; $T+3{ }^{\circ} \mathrm{C}$ is high temperature) treatments, after being maintained for 3 months in winter and summer conditions, $n=5$.

\begin{tabular}{lrrrr}
\hline & \multicolumn{4}{c}{$\begin{array}{c}\text { Chlorophyll } a \\
\mu \text { chlorophyll } g \mathrm{DW}^{-1}\end{array}$} \\
\cline { 2 - 5 } & $\mathrm{A}-p \mathrm{CO}_{2} / T$ & $\mathrm{H}-p \mathrm{CO}_{2} / T$ & $\mathrm{~A}-p \mathrm{CO}_{2} / T+3^{\circ} \mathrm{C}$ & $\mathrm{H}-p \mathrm{CO}_{2} / T+3^{\circ} \mathrm{C}$ \\
\hline Living L. corallioides & & & \\
Winter & $59.84( \pm 1.97)$ & $61.66( \pm 3.83)$ & $52.93( \pm 3.44)$ & $56.85( \pm 2.52)$ \\
Summer & $55.03( \pm 2.95)$ & $57.63( \pm 3.99)$ & $60.35( \pm 0.70)$ & $62.19( \pm 3.75)$ \\
\hline Dead L. corallioides & & & & \\
Winter & $47.09( \pm 2.72)$ & $39.39( \pm 5.65)$ & $39.15( \pm 2.20)$ & $46.36( \pm 2.19)$ \\
Summer & $52.21( \pm 1.92)$ & $36.30( \pm 1.83)$ & $43.63( \pm 0.90)$ & $47.96( \pm 2.54)$ \\
\hline
\end{tabular}

\section{Discussion}

The response of marine communities to increased temperature and $p \mathrm{CO}_{2}$ conditions is likely to be a complex function of direct effects of climate variables on species physiology and shifts in species interactions (Lord et al., 2017). Results show that predicted changes may alter interactions among calcifying and fleshy macroalgae via overgrowth of epiphytic algae and an increase in competition for light and nutrients with underlying maerl. Interactions between grazers and macroalgae were also affected because the grazer physiology was adversely affected by acidification and warming with potential consequences on epiphyte biomass regulation. Our results underscore the importance of examining communitylevel processes to integrate species interactions in the study of the impact of global change on marine ecosystems. This study also shows that seasonal variability represent an im- portant driver influencing the magnitude and the direction of species and community response to climate change.

Assemblage exhibited a strong seasonal pattern for all metabolic parameters, which is consistent with the higher metabolism in the summer for most of the species incubated at the specific scale. This higher metabolism in the summer has already been shown in urchins (Brockington and Peck, 2001), gastropods (Davies, 1966; Innes and Houlihan, 1985; Martin et al., 2006b), and living maerl (Potin et al., 1990; Martin et al., 2006a) and is strongly related to changes in numerous environmental and biological variables, such as light intensity and photoperiod, temperature, and nutrient or food availability (Godbold and Solan, 2013; Thomsen et al., 2013).

Assemblage GPP and $R$ were not affected by the high temperature and $p \mathrm{CO}_{2}$ conditions in the winter. Conversely, in the summer, GPP and $R$ increased under high $p \mathrm{CO}_{2}$ con- 
Table 7. Summary of the effects of $p \mathrm{CO}_{2}$ and temperature $(T)$ and their combined effect on gross production and respiration of the two epiphytic algae $R$. ardissonei and $S$. chordalis in the summer $(n=5)$. Statistical analyses were performed using a two-way crossed ScheirerRay-Hare test. Significant $p$ values are presented in bold $(\alpha=0.05)$. Degrees of freedom $=1$.

\begin{tabular}{|c|c|c|c|c|c|c|c|c|}
\hline & & & \multicolumn{2}{|c|}{$\begin{array}{l}\text { Net production } \\
\text { NPP }\end{array}$} & \multicolumn{2}{|c|}{$\begin{array}{c}\text { Gross production } \\
\text { GPP }\end{array}$} & \multicolumn{2}{|c|}{$\begin{array}{c}\text { Respiration } \\
R\end{array}$} \\
\hline & & & $F$ & $p$ value & $F$ & $p$ value & $F$ & $p$ value \\
\hline 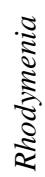 & 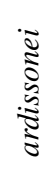 & $\begin{array}{l}T \\
p \mathrm{CO}_{2} \\
p \mathrm{CO}_{2} \times T\end{array}$ & $\begin{array}{l}0.8 \\
0.0 \\
1.0\end{array}$ & $\begin{array}{l}0.369 \\
0.960 \\
0.311\end{array}$ & $\begin{array}{l}0.2 \\
0.8 \\
1.0\end{array}$ & $\begin{array}{l}0.683 \\
0.381 \\
0.312\end{array}$ & $\begin{array}{l}1.3 \\
8.6 \\
0.7\end{array}$ & $\begin{array}{r}0.253 \\
\mathbf{0 . 0 0 3} \searrow \\
0.418\end{array}$ \\
\hline$\frac{\sqrt{5}}{\sqrt[3]{0}}$ & 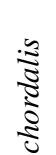 & $\begin{array}{l}T \\
p \mathrm{CO}_{2} \\
p \mathrm{CO}_{2} \times T\end{array}$ & $\begin{array}{l}0.1 \\
3.0 \\
5.8\end{array}$ & $\begin{array}{l}0.762 \\
0.082 \\
\mathbf{0 . 0 1 6}\end{array}$ & $\begin{array}{l}1.1 \\
5.5 \\
7.6\end{array}$ & $\begin{array}{l}0.317 \\
\mathbf{0 . 0 3 2} \\
\mathbf{0 . 0 1 4}\end{array}$ & $\begin{array}{l}5.5 \\
3.9 \\
0.0\end{array}$ & $\begin{array}{r}0.019 \nearrow \\
0.049 \nearrow \\
0.880\end{array}$ \\
\hline
\end{tabular}

Table 8. Results the analysis of variance testing the effects of temperature $(T)$ and $p \mathrm{CO}_{2}$ on net and gross primary production, respiration, and light and dark calcification rates, measured on assemblages $(n=5)$. Significant $p$ values are presented in bold $(\alpha=0.05)$. Degrees of freedom $=1$.

\begin{tabular}{|c|c|c|c|c|c|c|c|c|c|c|c|}
\hline & \multicolumn{2}{|c|}{$\begin{array}{c}\text { Net production } \\
\text { NPP }\end{array}$} & \multicolumn{2}{|c|}{$\begin{array}{c}\text { Gross production } \\
\text { GPP }\end{array}$} & \multicolumn{2}{|c|}{$\begin{array}{c}\text { Respiration } \\
R\end{array}$} & \multicolumn{2}{|c|}{$\begin{array}{l}\text { Light calcification } \\
\qquad G_{1}\end{array}$} & \multicolumn{2}{|c|}{$\begin{array}{l}\text { Dark calcification } \\
\qquad G_{\mathrm{d}}\end{array}$} \\
\hline & & $F$ & $p$ & $F$ & $p$ & $F$ & $p$ & $F$ & $p$ & $F$ & $p$ \\
\hline \multirow{7}{*}{ 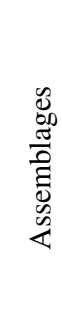 } & Winter & & & & & & & & & & \\
\hline & $T$ & 0.2 & 0.704 & 0.7 & 0.428 & 1.7 & 0.207 & 0.2 & 0.707 & 0.7 & 0.429 \\
\hline & $p \mathrm{CO}_{2}$ & 8.6 & $0.011 \nearrow$ & 0.1 & 0.717 & 1.6 & 0.228 & 27.3 & $<0.001 \searrow$ & 65.4 & $<0.001 \searrow$ \\
\hline & $p \mathrm{CO}_{2} \times T$ & 0.9 & 0.350 & 1.1 & 0.727 & 1.1 & 0.309 & 0.8 & 0.373 & 0.2 & 0.656 \\
\hline & $\begin{array}{l}\text { Summer } \\
T\end{array}$ & 2.1 & 0.166 & 1.6 & 0.225 & 0.5 & 0.513 & 40.2 & $<0.001 \nearrow$ & 6.8 & $0.020 \nearrow$ \\
\hline & $p \mathrm{CO}_{2}$ & 8.2 & $0.011 \nearrow$ & 14.2 & $0.002 \nearrow$ & 11.1 & $0.004 \nearrow$ & 16.6 & $<0.001 \backslash$ & 3.0 & 0.102 \\
\hline & $p \mathrm{CO}_{2} \times T$ & 1.9 & 0.192 & 1.3 & 0.275 & 0.3 & 0.595 & 0.8 & 0.384 & 3.6 & 0.077 \\
\hline
\end{tabular}

ditions. The response of assemblage GPP and $R$ appeared closely related to changes in epiphyte biomass and productivity. For instance, the biomass of maerl epiphytic algae was significantly higher in summer than in winter, which is consistent with other findings in the Bay of Brest (Guillou et al., 2002) and other Atlantic maerl beds (Peña and Barbara, 2010). The high biomass of epiphytic algae in the summer led to high contribution to oxygen fluxes. Under high $p \mathrm{CO}_{2}$ conditions, the higher availability of $\mathrm{CO}_{2}$ as substrate for photosynthesis may stimulate epiphyte productivity and growth (Koch et al., 2013). The two main epiphytic algae that grew during the experiments, $R$. ardissone $i$ and $S$. chordalis, are naturally found in maerl beds in Brittany (Peña et al., 2014). The response of the alga $S$. chordalis to increased temperature and $p \mathrm{CO}_{2}$ differed from that of $R$. ardissonei. This difference suggests that the response is speciesspecific, even among fleshy algae, as demonstrated by Kram et al. (2016). $R$. ardissonei GPP was not affected by increased temperature and $p \mathrm{CO}_{2}$, but its $R$ was significantly lower under high $p \mathrm{CO}_{2}$. Within the same genus, Cook et al. (1986) showed that Rhodymenia palmata can potentially use $\mathrm{HCO}_{3}^{-}$ as source of inorganic carbon for photosynthesis. The same process may occur in $R$. ardissonei, suggesting that this alga is not carbon-limited at current oceanic $p \mathrm{CO}_{2}$ levels. In contrast to $R$. ardissone $i$, increased $p \mathrm{CO}_{2}$ stimulated $S$. chordalis GPP under ambient conditions of temperature. In their study, Short et al. (2014) indicate that the overgrowth of filamentous algae occurs synergistically with high $p \mathrm{CO}_{2}$ levels and decreased photosynthesis in coralline algae. Here, the stimulation of epiphyte productivity and growth under high $p \mathrm{CO}_{2}$ is likely to increase the competition with underlying maerl, especially through reduction in incident light.

Although assemblages were mainly composed of living and dead maerl, the response of GPP and $R$ of $L$. coral- 


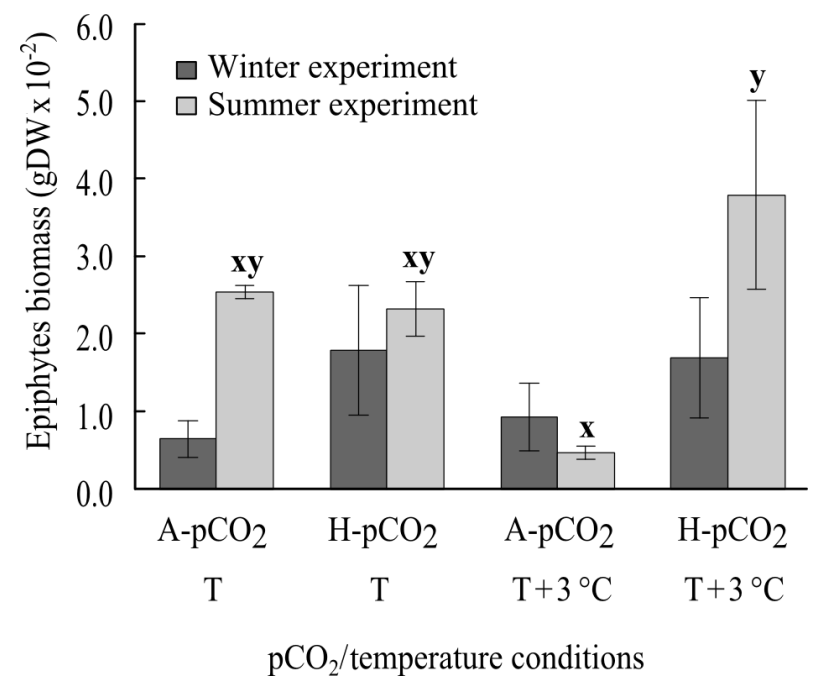

Figure 4. Biomass of epiphytic fleshy algae (mean $\pm \mathrm{SE}, n=5$ ) obtained in the different $p \mathrm{CO}_{2}\left(\mathrm{~A}-p \mathrm{CO}_{2}\right.$ is ambient $p \mathrm{CO}_{2} ; \mathrm{H}-p \mathrm{CO}_{2}$ is high- $p \mathrm{CO}_{2}$ ) and temperature ( $T$ is ambient temperature; $T+3{ }^{\circ} \mathrm{C}$ is high temperature) treatments after the 3-month experiments in winter (dark gray) and summer (light gray) experiments. Letters indicate significant differences between the four treatments $(x, y$ in the summer; Tukey HSD test). Tukey tests were performed when a significant effect of temperature or $p \mathrm{CO}_{2}$ was detected using twoway ANOVAs.

lioides to increased temperature and $p \mathrm{CO}_{2}$ differed from that observed in assemblages. For example, the temperature increase of $+3{ }^{\circ} \mathrm{C}$ reduced living $L$. corallioides $R$ in the winter but increased $R$ in the summer. Under high $p \mathrm{CO}_{2}$ conditions, although $\mathrm{CO}_{2}$ availability for photosynthesis was higher, no difference was observed in $L$. corallioides, probably due to the ability of this species to employ inorganic carbon acquisition mechanisms (Kübler and Dudgeon, 2015). Interestingly, GPP, $R$, and chlorophyll $a$ content of dead maerl were of the same magnitude as for living maerl. Although live algae prevent bio-fouling by shedding their surface layers (Keats et al., 1997; Villas Bôas and Figueiredo, 2004), post-mortem colonisation by photosynthetic endolithic assemblages may occur within dead crusts (Diaz-Pulido et al., 2012). Moreover, dead thalli may represent a substrate for the settlement of crustose coralline algae (CCA) that cover small parts of some thalli. CCA colonisation may also contribute to the observed GPP and $R$ values. In dead maerl, only $R$ decreased under high $p \mathrm{CO}_{2}$, while no effect was detected for GPP.

These findings also suggest the importance of dead maerl to assemblage carbonate fluxes during the experiments. For example, endolithic algae appear to play an important role in the dissolution of a CCA species, Porolithon onkodes (ReyesNivia et al., 2014). Through their photosynthesis, endolithic algae may elevate interstitial $\mathrm{pH}$ within the $P$. onkodes skeleton (Reyes-Nivia et al., 2013), increasing carbonate cement precipitation (Diaz-Pulido et al., 2014). Within dead L. coral-
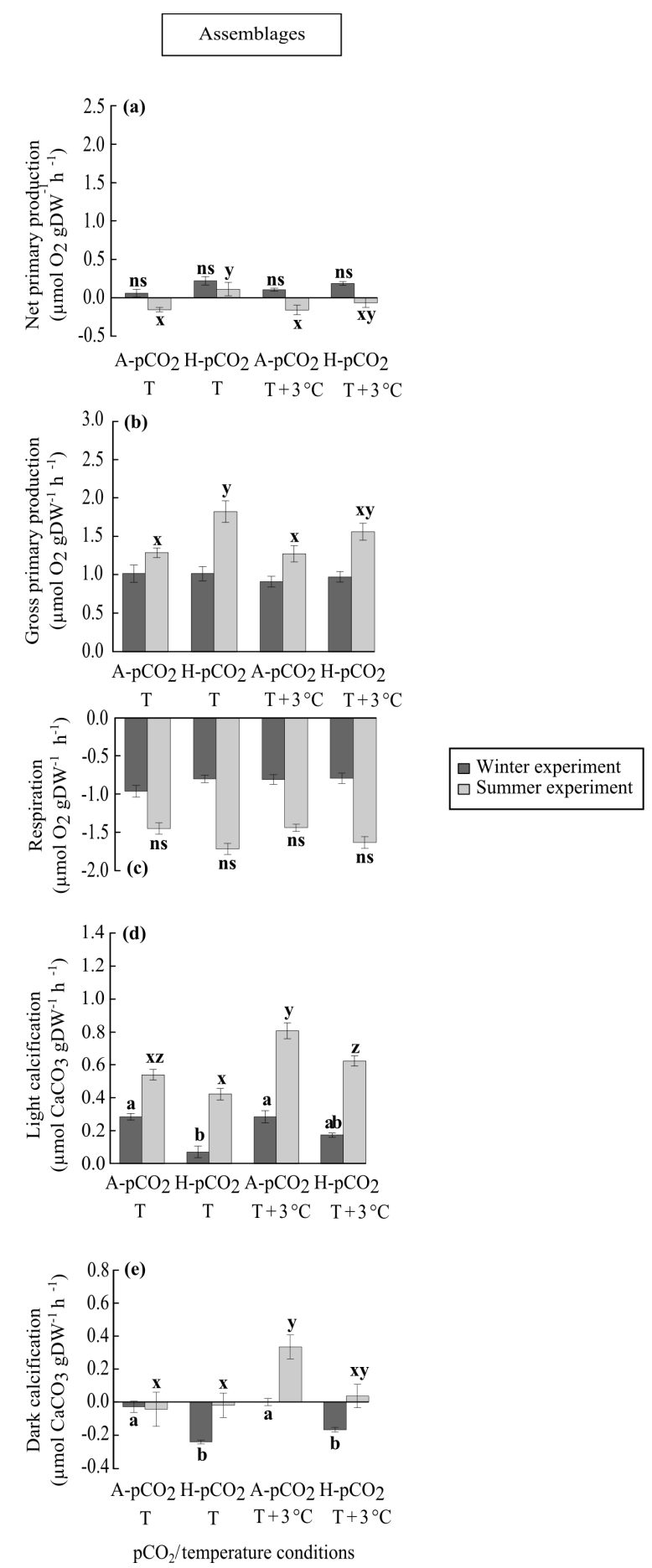

Figure 5. Net and gross primary production (a and b, respectively), respiration (c), and light and dark calcification rates (d and $\mathbf{e}$, respectively) rates (mean $\pm \mathrm{SE}, n=5$ ) of assemblages in the different $p \mathrm{CO}_{2}\left(\mathrm{~A}-p \mathrm{CO}_{2}\right.$ is ambient $p \mathrm{CO}_{2} ; \mathrm{H}-p \mathrm{CO}_{2}$ is high- $\left.p \mathrm{CO}_{2}\right)$ and temperature ( $T$ is ambient temperature; $T+3{ }^{\circ} \mathrm{C}$ is high temperature) treatments. The assemblages were maintained during 3 months in winter (dark gray) and summer conditions (light gray). Letters indicate significant differences between the four treatments in winter $(\mathrm{a}, \mathrm{b}, \mathrm{c})$ and summer $(\mathrm{x}, \mathrm{y}, \mathrm{z})$ conditions (Tukey HSD test). ns is not significant. Tukey tests were performed when a significant effect of temperature or $p \mathrm{CO}_{2}$ was detected using two-way ANOVAs. 
lioides, the presence of endolithic algae combined with the presence of small patches of CCA on the surface of thalli may explain the calcification rates observed in light and dissolution in dark. Considering the high $\mathrm{Mg}$ content in the skeleton of $L$. corallioides, increased $p \mathrm{CO}_{2}$ likely promotes the dissolution of dead thalli. Alternatively, the increase in dissolution observed in the present study may be associated with a reduction of CCA recruitment over the surface of dead thalli under acidified conditions (Jokiel et al., 2008; Ordoñez et al., 2014). These results are consistent with the negative response to increased $p \mathrm{CO}_{2}$ observed here in assemblage $G_{1}$ and $G_{\mathrm{d}}$ values, which appeared strongly related to the response of living maerl calcification rates. The high sensitivity of coralline algae to ocean acidification has already been attributed to their high Mg-calcite content (Morse et al., 2006; Hofmann and Bischof, 2014). In the present study, the $p \mathrm{CO}_{2}$ increase had adverse consequences on assemblage $G_{\mathrm{d}}$ in both winter and summer. In the dark, assemblage $R$ reduced seawater $\mathrm{pH}$ by releasing $\mathrm{CO}_{2}$ and hindered the precipitation of $\mathrm{CaCO}_{3}$ (Cornwall et al., 2013). Under high $p \mathrm{CO}_{2}$ conditions, the combined effect of acidification and assemblage $R$ in the dark is likely to increase the sensitivity of living and dead L. corallioides to dissolution (Andersson et al., 2009).

Moreover, as discussed above, the overgrowth of epiphytic algae under high $p \mathrm{CO}_{2}$ increased assemblage $R$ in the dark. Therefore, the negative effect of ocean acidification on $L$. corallioides $G_{\mathrm{d}}$ would be exacerbated by the presence of epiphytic algae, which promote a decline in $\mathrm{pH}$ in the dark. In light, several studies have suggested that moderate growth of fleshy macroalgal communities may reduce the impact of ocean acidification on coralline calcification by reducing the $\mathrm{CO}_{2}$ concentration of seawater through photosynthesis (Semesi et al., 2009; Short et al., 2014). Conversely, other studies showed that the overgrowth of epiphytic fleshy algae may shade underlying coralline algae and reduce coralline net calcification rates (Garrabou and Ballesteros, 2000; Martin and Gattuso, 2009). The present findings support this idea because a decline in assemblage $G_{1}$ was observed under high $p \mathrm{CO}_{2}$ and high epiphyte biomass. Under high $p \mathrm{CO}_{2}$, the overgrowth of epiphytic fleshy algae induced by ocean acidification in the summer may reduce light, oxygen, and nutrient availability for underlying maerl, affecting its primary production and calcification (D'Antonio, 1985; Short et al., 2014). Thus, overgrown maerl would be negatively affected by the direct effect of ocean acidification on calcification rates and indirect effects due to shifts in competition dynamics with fleshy epiphytic algae (Kuffner et al., 2008). However, the response of epiphytic algae is likely to be speciesspecific and it appears difficult to generalize the impacts of epiphytic algae on coralline algae.

In regard to the present results, the regulation of epiphyte biomass by grazers appears essential to maintain the proper functioning of maerl bed communities (Guillou et al., 2002). The importance of grazers to control epiphytes growth in aquaria has been shown by Jokiel et al. (2008). In mol- lusks and urchins, several studies have demonstrated a link between feeding rates and other metabolic processes, such as respiration, calcification, and excretion (Carr and Bruno, 2013; Navarro et al., 2013; Noisette et al., 2016). In mollusks, a wide range of responses to ocean acidification and warming have been revealed (Gazeau et al., 2013; Parker et al., 2013). The differences in sensitivity of mollusks to ocean acidification depend on several parameters, such as the form of $\mathrm{CaCO}_{3}$ they precipitate during calcification (Ries et al., 2009) and their ability to regulate the acid-base balance (Gutowska et al., 2010). Our results corroborate these studies, given that G. magus and J. exasperatus responded differently to acidification and warming. Increased temperature and $p \mathrm{CO}_{2}$ had no effect on $G$. magus with regard to the metabolic functions tested. However, despite the apparent resistance of G. magus to the applied changes, other physiological parameters that we did not test here may have been affected, such as feeding rates, somatic growth, enzyme activity, or immune response (Parker et al., 2013). The respiration rates of $J$. exasperatus showed a decline under high $p \mathrm{CO}_{2}$ in the winter. The lower growth of epiphytes and biofilm in winter may reduce the energy available to maintain the metabolism under stressful conditions (Thomsen et al., 2013; Pansch et al., 2014). This reduced energy availability may induce changes in energy partitioning and decrease $R$ under high $p \mathrm{CO}_{2}$. In the summer, the increased $R$ under high $p \mathrm{CO}_{2}$ can be attributed to higher food supply, which is likely to increase the resistance of $J$. exasperatus to climate change, as reported for several marine taxa (Ramajo et al., 2016).

Given the relatively high resistance of G. magus and J. exasperatus to predicted changes, the metabolic response of $P$. miliaris appears to have stronger implications on assemblage functioning. For example, $P$. miliaris is considered as one of the main macro-epiphytic grazers on maerl beds in the Bay of Brest (Guillou et al., 2002). During the experiments, $P$. miliaris likely played an important role in the regulation of epiphytic biomass. The response of $G_{1}$ to temperature and $p \mathrm{CO}_{2}$ changes was complex. The interaction between temperature and $p \mathrm{CO}_{2}$ observed in the summer may cause changes in energy partitioning, thereby inducing a trade-off between metabolic processes at the expense of respiration and excretion (Garilli et al., 2015). However, the effect of temperature and $p \mathrm{CO}_{2}$ on the calcification of $P$. miliaris must be considered carefully. For instance, urchins defecated carbonate pellets following consumption of maerl thalli. These feces are likely to dissolve during incubation, introducing a bias in the measurement of calcification (Gazeau et al., 2015). In the summer, temperature increase by $3{ }^{\circ} \mathrm{C}$ reduced $P$. miliaris respiration rates. Moreover, the decrease in excretion under high temperature and $p \mathrm{CO}_{2}$ conditions was modulated by the interaction between these two factors. Temperature is a major factor affecting physiological processes in ectotherms such as metabolic rates and growth (Kordas et al., 2011). In P. miliaris, summer temperatures are likely to exceed the physiological thresholds of organisms, inducing a metabolic decline 
when maintained at $20^{\circ} \mathrm{C}$. Although this decline has only been measured for respiration and excretion, the increase in temperature is also likely to affect sea urchin feeding efficiency (Thomas et al., 2000; Carr and Bruno, 2013). Therefore, the ability of $P$. miliaris to regulate epiphyte biomass may be significantly altered under predicted acidification and warming conditions.

In addition to the impact of climate change on grazerfleshy macroalgae interactions, predicted changes may also considerably alter the interaction between grazers and coralline algae. Asnaghi et al. (2013) demonstrated that the grazing activity by urchins may exacerbate $p \mathrm{CO}_{2}$ effects on coralline algae. Ocean acidification may alter the structural integrity of coralline algae, increasing its sensitivity to grazing (Johnson and Carpenter, 2012; Ragazzola et al., 2012). Coralline algae may thus be more susceptible to grazing by urchins, which also benefit from a higher carbonate uptake from their diet to modulate their response to ocean acidification (Asnaghi et al., 2013). In L. corallioides, the decrease in calcification rates may alter its structural integrity and increase its susceptibility to grazing, especially by urchins, which are considered to important bioeroders of coralline algae in marine ecosystems (Ballesteros, 2006; O'Leary and McClanahan, 2010), particularly in maerl beds (Lawrence, 2013).

In conclusion, the community response to climate change does not appear to only be the result of individual species' metabolic responses but also strongly depend on shifts in species interactions. In contrast with other studies, which have shown larger impacts of the combination of increased $p \mathrm{CO}_{2}$ and temperature than that of these factors alone (Reynaud et al., 2003; Anthony et al., 2008; Martin and Gattuso, 2009; Rodolfo-Metalpa et al., 2010), we showed here that the effects of $p \mathrm{CO}_{2}$ and temperature on maerl bed communities were weakened when these factors were combined. Here, we also demonstrated that climate change may affect grazer physiology, with major consequences on their ability to regulate epiphyte biomass. Epiphyte overgrowth is thus likely to adversely affect underlying coralline algae, increasing the shading effect at light and the $\mathrm{pH}$ decline in the dark. Climate change may also affect other components that we did not assess in the present study, such as algal palatability and potential changes in grazer trophic behaviour (Campbell et al., 2014; Duarte et al., 2015; Poore et al., 2013, 2016). Algal palatability to grazers may also be affected by predicted changes through shifts in the composition and the quantity of allelopathic compounds, as suggested by Del Monaco et al. (2017). In order to better understand the consequences of climate change on ecosystem functioning, further work should focus on the response of marine communities and consider more specifically shifts in species interactions, including changes in trophic interactions between algae and grazers.
Data availability. Data are available by direct request to the corresponding author.

\section{The Supplement related to this article is available online at https://doi.org/10.5194/bg-14-5359-2017-supplement.}

Author contributions. EL, SM, PR, JG, and JC designed the experiments; EL, SM, and JC collected the data; EL and ML analysed the data; EL, SM, PR, and JG prepared the manuscript with contributions from all co-authors.

Competing interests. The authors declare that they have no conflict of interest.

Acknowledgements. The authors thank the CRBM (Center of Marine Biologic Resources) at the Station Biologique de Roscoff for its kind permission to use their premises for the duration of the experiments. We are grateful to Olivier Bohner for his laboratory assistance and for the help in system maintenance. We also thank Murielle Jam for freeze-drying samples. We acknowledge the crew of the research vessel Albert Lucas for its help with species collection. We also thank the SOMLIT (Service d'Observation en Milieu LITtoral, INSU-CNRS) program for the temperature data sets provided. We thank Carolyn Engel-Gautier for language editing of the manuscript. This work was supported by the Brittany Regional Council, the French National Research Agency via the "Investment for the Future" program IDEALG (no. ANR-10-BTBR-04), and the French national EC2CO program ("Écosphère Continentale et Côtière", project MAERLCHANGE).

Edited by: Clare Woulds

Reviewed by: Laurie Hofmann, G. Diaz-Pulido, and William Ross Hunter

\section{References}

Alsterberg, C., Eklof, J. S., Gamfeldt, L., Havenhand, J. N., and Sundback, K.: Consumers mediate the effects of experimental ocean acidification and warming on primary producers, P. Natl. Acad. Sci. USA, 110, 8603-8608, https://doi.org/10.1073/pnas.1303797110, 2013.

Amado-Filho, G. M., Maneveldt, G. W., Pereira, G. H., Manso, R. C. C., Bahia, R. G., Barros-Barreto, M. B., and Guimaraes, S.: Seaweed diversity associated with a Brazilian tropical rhodolith bed, Cienc. Mar., 36, 371-391, 2010.

Andersson, A. J., Kuffner, I. B., Mackenzie, F. T., Jokiel, P. L., Rodgers, K. S., and Tan, A.: Net Loss of $\mathrm{CaCO}_{3}$ from a subtropical calcifying community due to seawater acidification: mesocosm-scale experimental evidence, Biogeosciences, 6 , 1811-1823, https://doi.org/10.5194/bg-6-1811-2009, 2009.

Anthony, K. R. N., Kline, D. I., Diaz-Pulido, G., Dove, S., and Hoegh-Guldberg, O.: Ocean acidification causes bleaching and 
productivity loss in coral reef builders, P. Natl. Acad. Sci. USA, 105, 17442-17446, https://doi.org/10.1073/pnas.0804478105, 2008.

Asnaghi, V., Chiantore, M., Mangialajo, L., Gazeau, F., Francour, P., Alliouane, S., and Gattuso, J. P.: Cascading effects of ocean acidification in a rocky subtidal community, Plos One, 8, e61978, https://doi.org/10.1371/journal.pone.0061978, 2013.

Auster, P. J., Estes, J. A., and Coleman, F. C.: Species interactions in marine communities: the invisible fabric of nature, Bull. Mar. Sci., 89, 3-9, https://doi.org/10.5343/bms.2012.1051, 2013.

Baggini, C., Salomidi, M., Voutsinas, E., Bray, L., Krasakopoulou, E., and Hall-Spencer, J. M.: Seasonality affects macroalgal community response to increases in $p \mathrm{CO}_{2}$, Plos One, 9, e106520, https://doi.org/10.1371/journal.pone.0106520, 2014.

Ballesteros, E.: Mediterranean coralligenous assemblages: A synthesis of present knowledge, in: Oceanography and Marine Biology - an Annual Review, edited by: Gibson, R. N., Atkinson, R. J. A., and Gordon, J. D. M., Crc Press-Taylor \& Francis Group, Boca Raton, 123-195, 2006.

Bopp, L., Resplandy, L., Orr, J. C., Doney, S. C., Dunne, J. P., Gehlen, M., Halloran, P., Heinze, C., Ilyina, T., Seferian, R., Tjiputra, J., and Vichi, M.: Multiple stressors of ocean ecosystems in the 21st century: projections with CMIP5 models, Biogeosciences, 10, 6225-6245, https://doi.org/10.5194/bg-106225-2013, 2013.

Brockington, S. and Peck, L. S.: Seasonality of respiration and ammonium excretion in the Antarctic echinoid Sterechinus neumayeri, Mar. Ecol. Prog. Ser., 219, 159-168, https://doi.org/10.3354/meps219159, 2001

Campbell, J. E., Craft, J. D., Muehllehner, N., Langdon, C., and Paul, V. J.: Responses of calcifying algae (Halimeda spp.) to ocean acidification: implications for herbivores, Mar. Ecol. Prog. Ser., 514, 43-56, https://doi.org/10.3354/meps10981, 2014.

Carr, L. A. and Bruno, J. F.: Warming increases the top-down effects and metabolism of a subtidal herbivore, PeerJ, 1, e109, https://doi.org/10.7717/peerj.109, 2013.

Cook, C. M., Lanaras, T., and Colman, B.: Evidence for bicarbonate transport in species of red and brown macrophytic marine-algae, J. Exp. Bot., 37, 977-984, https://doi.org/10.1093/jxb/37.7.977, 1986.

Cornwall, C. E., Hepburn, C. D., McGraw, C. M., Currie, K. I., Pilditch, C. A., Hunter, K. A., Boyd, P. W., and Hurd, C. L.: Diurnal fluctuations in seawater $\mathrm{pH}$ influence the response of a calcifying macroalga to ocean acidification, Proc. Roy. Soc. B, 280, 20132201, https://doi.org/10.1098/rspb.2013.2201, 2013.

D'Antonio, C.: Epiphytes on the rocky intertidal red alga Rhodomela latrix (Turner) C. Agardh: Negative effects on the host and food for herbivores, J. Exp. Mar. Biol. Ecol., 86, 197218, https://doi.org/10.1016/0022-0981(85)90103-0, 1985.

Davies, S. P.: Physiological ecology of Patella, I. The effect of body size and temperature on metabolic rate, J. Mar. Biol. Assoc. UK, 46, 647-658, https://doi.org/10.1017/S0025315400033397, 1966.

Del Monaco, C., Hay, M. E., Gartrell, P., Mumby, P. J., and DiazPulido, G.: Effects of ocean acidification on the potency of macroalgal allelopathy to a common coral, Sci. Rep., 7, 41053, https://doi.org/10.1038/srep41053, 2017.

Diaz-Pulido, G., Anthony, K. R. N., Kline, D. I., Dove, S., and Hoegh-Guldberg, O.: Interactions between ocean acidification and warming on the mortality and dissolution of coralline algae, J. Phycol., 48, 32-39, https://doi.org/10.1111/j.15298817.2011.01084.x, 2012.

Diaz-Pulido, G., Nash, M. C., Anthony, K. R. N., Bender, D., Opdyke, B. N., Reyes-Nivia, C., and Troitzsch, U.: Greenhouse conditions induce mineralogical changes and dolomite accumulation in coralline algae on tropical reefs, Nat. Commun., 5, 3310, https://doi.org/10.1038/ncomms4310, 2014.

Dickson, A. G., Sabine, C. L., and Christian, J. R.: Guide to best practices for ocean $\mathrm{CO}_{2}$ measurements. In: PICES special publication, North Pacific Marine Science Organization, Sidney, British Columbia, 3, 191 pp., 2007.

Duarte, C., Lopez, J., Benitez, S., Manriquez, P. H., Navarro, J. M., Bonta, C. C., Torres, R., and Quijón, P.: Ocean acidification induces changes in algal palatability and herbivore feeding behavior and performance, Oecologia, 180, 453-462, https://doi.org/10.1007/s00442-015-3459-3, 2015.

Dupont, S., Ortega-Martinez, O., and Thorndyke, M.: Impact of near-future ocean acidification on echinoderms, Ecotoxicology, 19, 449-462, https://doi.org/10.1007/s10646-010-0463-6, 2010.

Dutertre, M., Grall, J., Ehrhold, A., and Hamon, D.: Environmental factors affecting maerl bed structure in Brittany (France), Eur. J. Phycol., 50, 371-383, https://doi.org/10.1080/09670262.2015.1063698, 2015.

Foster, M. S., McConnico, L. M., Lundsten, L., Wadsworth, T., Kimball, T., Brooks, L. B., Medina-Lopez, M., RiosmenaRodriguez, R., Hernandez-Carmona, G., Vasquez-Elizondo, R. M., Johnson, S., and Steller, D. L.: Diversity and natural history of a Lithothamnion muelleri-Sargassum horridum community in the Gulf of California, Cienc. Mar., 33, 367-384, 2007.

Garilli, V., Rodolfo-Metalpa, R., Scuderi, D., Brusca, L., Parrinello, D., Rastrick, S. P. S., Foggo, A., Twitchett, R. J., Hall-Spencer, J. M., and Milazzo, M.: Physiological advantages of dwarfing in surviving extinctions in high- $\mathrm{CO}_{2}$ oceans, Nature Climate Change, 5, 678-682, 2015.

Garrabou, J. and Ballesteros, E.: Growth of Mesophyllum alternans and Lithophyllum frondosum (Corallinales, Rhodophyta) in the northwestern Mediterranean, Eur. J. Phycol., 35, 1-10, 2000.

Gazeau, F., Parker, L. M., Comeau, S., Gattuso, J. P., O’Connor, W. A., Martin, S., Pörtner, H. O., and Ross, P. M.: Impacts of ocean acidification on marine shelled molluscs, Mar. Biol., 160, 2207-2245, https://doi.org/10.1007/s00227-013-2219-3, 2013.

Gazeau, F., Urbini, L., Cox, T. E., Alliouane, S., and Gattuso, J. P.: Comparison of the alkalinity and calcium anomaly techniques to estimate rates of net calcification, Mar. Ecol. Prog. Ser., 527, 1-12, https://doi.org/10.3354/meps11287, 2015.

Godbold, J. A. and Solan, M.: Long-term effects of warming and ocean acidification are modified by seasonal variation in species responses and environmental conditions, Philos. T. Roy. Soc. B, 368, 20130186, https://doi.org/10.1098/rstb.2013.0186, 2013.

Grall, J. and Hall-Spencer, J. M.: Problems facing maerl conservation in Brittany, Aquat. Conserv.-Mar. Freshw. Ecosyst., 13, S55-S64, https://doi.org/10.1002/aqc.568, 2003.

Grall, J., Le Loc'h, F., Guyonnet, B., and Riera, P.: Community structure and food web based on stable isotopes $\left(\delta^{15} \mathrm{~N}\right.$ and $\left.\delta^{13} \mathrm{C}\right)$ analysis of a North Eastern Atlantic maerl bed, J. Exp. Mar. Biol. Ecol., 338, 1-15, https://doi.org/10.1016/j.jembe.2006.06.013, 2006. 
Guillou, M., Grall, J., and Connan, S.: Can low sea urchin densities control macro-epiphytic biomass in a northeast Atlantic maerl bed ecosystem (Bay of Brest, Brittany, France)?, J. Mar. Biol. Assoc. UK, 82, 867-876, https://doi.org/10.1017/s0025315402006276, 2002.

Gutowska, M. A., Melzner, F., Langenbuch, M., Bock, C., Claireaux, G., and Pörtner, H.-O.: Acid-base regulatory ability of the cephalopod (Sepia officinalis) in response to environmental hypercapnia, J. Comp. Physiol. B, 180, 323-335, 2010.

Hale, R., Calosi, P., McNeill, L., Mieszkowska, N., and Widdicombe, S.: Predicted levels of future ocean acidification and temperature rise could alter community structure and biodiversity in marine benthic communities, Oikos, 120, 661-674, https://doi.org/10.1111/j.1600-0706.2010.19469.x, 2011.

Hansson, L.-A., Nicolle, A., Graneli, W., Hallgren, P., Kritzberg, E., Persson, A., Bjork, J., Nilsson, P. A., and Bronmark, C.: Food-chain length alters community responses to global change in aquatic systems, Nature Climate Change, 3, 228-233, 2012.

Harley, C. D. G., Anderson, K. M., Demes, K. W., Jorve, J. P., Kordas, R. L., Coyle, T. A., and Graham, M. H.: Effects of climate change on global seaweed communities, J. Phycol., 48, 10641078, https://doi.org/10.1111/j.1529-8817.2012.01224.x, 2012.

Hily, C., Potin, P., and Floch, J. Y.: Structure of subtidal algal assemblages on soft-bottom sediments: fauna/flora interactions and role of disturbances in the Bay of Brest, France, Mar. Ecol. Prog. Ser., 85, 115-130, https://doi.org/10.3354/meps085115, 1992.

Hofmann, L. C. and Bischof, K.: Ocean acidification effects on calcifying macroalgae, Aquat. Biol., 22, 261-279, https://doi.org/10.3354/ab00581, 2014.

Innes, A. J. and Houlihan, D. F.: Aquatic and aerial oxygen consumption of cool temperate gastropods: A comparison with some mediterranean species, Comp. Biochem. Phys. A, 82, 105-109, https://doi.org/10.1016/0300-9629(85)90712-1, 1985.

Jellison, B. M., Ninokawa, A. T., Hill, T. M., Sanford, E., and Gaylord, B.: Ocean acidification alters the response of intertidal snails to a key sea star predator, P. R. Soc. Lond. B Bio., 283, 20160890, https://doi.org/10.1098/rspb.2016.0890, 2016.

Johnson, M. D. and Carpenter, R. C.: Ocean acidification and warming decrease calcification in the crustose coralline alga Hydrolithon onkodes and increase susceptibility to grazing, J. Exp. Mar. Biol. Ecol., 434, 94-101, https://doi.org/10.1016/j.jembe.2012.08.005, 2012.

Jokiel, P. L., Rodgers, K. S., Kuffner, I. B., Andersson, A. J., Cox, E. F., and Mackenzie, F. T.: Ocean acidification and calcifying reef organisms: a mesocosm investigation, Coral Reefs, 27, 473-483, https://doi.org/10.1007/s00338-008-0380-9, 2008.

Keats, D. W., Knight, M. A., and Pueschel, C. M.: Antifouling effects of epithallial shedding in three crustose coralline algae (Rhodophyta, Coralinales) on a coral reef, J. Exp. Mar. Biol. Ecol., 213, 281-293, 1997.

Koch, M., Bowes, G., Ross, C., and Zhang, X. H.: Climate change and ocean acidification effects on seagrasses and marine macroalgae, Glob. Change Biol., 19, 103-132, https://doi.org/10.1111/j.1365-2486.2012.02791.x, 2013.

Kordas, R. L., Harley, C. D. G., and O'Connor, M. I.: Community ecology in a warming world: The influence of temperature on interspecific interactions in marine systems, J. Exp. Mar. Biol. Ecol., 400, 218-226, https://doi.org/10.1016/j.jembe.2011.02.029, 2011.
Kram, S. L., Price, N. N., Donham, E. M., Johnson, M. D., Kelly, E. L. A., Hamilton, S. L., and Smith, J. E.: Variable responses of temperate calcified and fleshy macroalgae to elevated $p \mathrm{CO}_{2}$ and warming, Ices J. Mar. Sci., 73, 693-703, https://doi.org/10.1093/icesjms/fsv168, 2016.

Kroeker, K. J., Micheli, F., and Gambi, M. C.: Ocean acidification causes ecosystem shifts via altered competitive interactions, Nature Climate Change, 3, 156-159, https://doi.org/10.1038/nclimate1680, 2012.

Kroeker, K. J., Kordas, R. L., Crim, R., Hendriks, I. E., Ramajo, L., Singh, G. S., Duarte, C. M., and Gattuso, J. P.: Impacts of ocean acidification on marine organisms: quantifying sensitivities and interaction with warming, Glob. Change Biol., 19, 1884-1896, https://doi.org/10.1111/gcb.12179, 2013.

Kübler, J. E. and Dudgeon, S. R.: Predicting effects of ocean acidification and warming on algae lacking carbon concentrating mechanisms, Plos One, 10, e0132806, https://doi.org/10.1371/journal.pone.0132806, 2015.

Kuffner, I. B., Andersson, A. J., Jokiel, P. L., Rodgers, K. S., and Mackenzie, F. T.: Decreased abundance of crustose coralline algae due to ocean acidification, Nat. Geosci., 1, 114-117, https://doi.org/10.1038/ngeo100, 2008.

Lawrence, J. M.: Sea Urchins: Biology and Ecology, 3rd Edition, Sea Urchins: Biology and Ecology, 3rd Edn., Elsevier Academic Press Inc, San Diego, California, USA, 531 pp., 2013.

Lord, J. P., Barry, J. P., and Graves, D.: Impact of climate change on direct and indirect species interactions, Mar. Ecol. Prog. Ser., 571, 1-11, 2017.

Martin, S. and Gattuso, J. P.: Response of Mediterranean coralline algae to ocean acidification and elevated temperature, Glob. Change Biol., 15, 2089-2100, https://doi.org/10.1111/j.13652486.2009.01874.x, 2009.

Martin, S. and Hall-Spencer, J. M.: Effects of ocean warming and acidification on rhodolith/maërl beds, in: Rhodolith/maërl beds: a global perspective, edited by: Riosmena-Rodríguez, R., Nelson, W., and Aguirre, J., Coastal Research Library, Springer International Publishing, Cham, Vol. 15, 55-85, 2016.

Martin, S., Castets, M. D., and Clavier, J.: Primary production, respiration and calcification of the temperate free-living coralline alga Lithothamnion corallioides, Aquat. Bot., 85, 121-128, https://doi.org/10.1016/j.aquabot.2006.02.005, 2006a.

Martin, S., Thouzeau, G., Chauvaud, L., Jean, F., Guerin, L., and Clavier, J.: Respiration, calcification, and excretion of the invasive slipper limpet, Crepidula fornicata L.: Implications for carbon, carbonate, and nitrogen fluxes in affected areas, Limnol. Oceanogr., 51, 1996-2007, 2006b.

Martin, S., Clavier, J., Chauvaud, L., and Thouzeau, G.: Community metabolism in temperate maerl beds, I. Carbon and carbonate fluxes, Mar. Ecol. Prog. Ser., 335, 19-29, https://doi.org/10.3354/meps335019, 2007.

Martin, S., Cohu, S., Vignot, C., Zimmerman, G., and Gattuso, J. P.: One-year experiment on the physiological response of the Mediterranean crustose coralline alga, Lithophyllum cabiochae, to elevated $p \mathrm{CO}_{2}$ and temperature, Ecol. Evolut., 3, 676-693, https://doi.org/10.1002/ece3.475, 2013.

McCoy, S. J. and Kamenos, N. A.: Coralline algae (Rhodophyta) in a changing world: integrating ecological, physiological, and geochemical responses to global change, J. Phycol., 51, 6-24, https://doi.org/10.1111/jpy.12262, 2015. 
Morse, J. W., Andersson, A. J., and Mackenzie, F. T.: Initial responses of carbonate-rich shelf sediments to rising atmospheric $p \mathrm{CO}_{2}$ and "ocean acidification": Role of high Mg-calcites, Geochim. Cosmochim. Ac., 70, 5814-5830, https://doi.org/10.1016/j.gca.2006.08.017, 2006.

Navarro, J. M., Torres, R., Acuña, K., Duarte, C., Manriquez, P. H., Lardies, M., Lagos, N. A., Vargas, C., and Aguilera, V.: Impact of medium-term exposure to elevated $p \mathrm{CO}_{2}$ levels on the physiological energetics of the mussel Mytilus chilensis, Chemosphere, 90, 1242-1248, https://doi.org/10.1016/j.chemosphere.2012.09.063, 2013.

Noisette, F., Bordeyne, F., Davoult, D., and Martin, S.: Assessing the physiological responses of the gastropod Crepidula fornicata to predicted ocean acidification and warming, Limnol. Oceanogr., 61, 430-444, https://doi.org/10.1002/lno.10225, 2016.

O'Connor, M. I., Gilbert, B., and Brown, C. J.: Theoretical predictions for how temperature affects the dynamics of interacting herbivores and plants, Am. Nat., 178, 626-638, https://doi.org/10.1086/662171, 2011.

O'Leary, J. K. and McClanahan, T. R.: Trophic cascades result in large-scale coralline algae loss through differential grazer effects, Ecology, 91, 3584-3597, https://doi.org/10.1890/092059.1, 2010.

Olabarria, C., Arenas, F., Viejo, R. M., Gestoso, I., Vaz-Pinto, F., Incera, M., Rubal, M., Cacabelos, E., Veiga, P., and Sobrino, C.: Response of macroalgal assemblages from rockpools to climate change: effects of persistent increase in temperature and $\mathrm{CO}_{2}$, Oikos, 122, 1065-1079, https://doi.org/10.1111/j.16000706.2012.20825.x, 2013.

Ordoñez, A., Doropoulos, C., and Diaz-Pulido, G.: Effects of ocean acidification on population dynamics and community structure of crustose coralline algae, Biol. Bull., 226, 255-268, https://doi.org/10.1086/BBLv226n3p255, 2014.

Pajusalu, L., Martin, G., and Pollumae, A.: Results of laboratory and field experiments of the direct effect of increasing $\mathrm{CO}_{2}$ on net primary production of macroalgal species in brackish-water ecosystems, P. Est. Acad. Sci., 62, 148-154, https://doi.org/10.3176/proc.2013.2.09, 2013.

Pansch, C., Schaub, I., Havenhand, J., and Wahl, M.: Habitat traits and food availability determine the response of marine invertebrates to ocean acidification, Glob. Change Biol., 20, 265-277, https://doi.org/10.1111/gcb.12478, 2014.

Parker, L. M., Ross, P. M., O'Connor, W. A., Pörtner, H.-O., Scanes, E., and Wright, J. M.: Predicting the response of molluscs to the impact of ocean acidification, Biology, 2, 651-692, 2013.

Peña, V. and Barbara, I.: Seasonal patterns in the maerl community of shallow European Atlantic beds and their use as a baseline for monitoring studies, Eur. J. Phycol., 45, 327-342, https://doi.org/10.1080/09670261003586938, 2010.

Peña, V., Bárbara, I., Grall, J., Maggs, C. A., and Hall-Spencer, J. M.: The diversity of seaweeds on maerl in the NE Atlantic, Mar. Biodivers., 44, 533-551, https://doi.org/10.1007/s12526014-0214-7, 2014.

Poore, A. G. B., Graba-Landry, A., Favret, M., Brennand, H. S., Byrne, M., and Dworjanyn, S. A.: Direct and indirect effects of ocean acidification and warming on a marine plant-herbivore interaction, Oecologia, 173, 1113-1124, https://doi.org/10.1007/s00442-013-2683-y, 2013.
Poore, A. G. B., Graham, S. E., Byrne, M., and Dworjanyn, S. A.: Effects of ocean warming and lowered $\mathrm{pH}$ on algal growth and palatability to a grazing gastropod, Mar. Biol., 163, 1-11, https://doi.org/10.1007/s00227-016-2878-y, 2016.

Potin, P., Floch, J. Y., Augris, C., and Cabioch, J.: Annual growth rate of the calcareous red alga Lithothamnion corallioides (Corallinales, Rhodophyta) in the bay of Brest, France, Hydrobiologia, 204, 263-267, https://doi.org/10.1007/bf00040243, 1990.

Ragazzola, F., Foster, L. C., Form, A., Anderson, P. S. L., Hansteen, T. H., and Fietzke, J.: Ocean acidification weakens the structural integrity of coralline algae, Glob. Change Biol., 18, 2804-2812, https://doi.org/10.1111/j.1365-2486.2012.02756.x, 2012.

Ramajo, L., Perez-Leon, E., Hendriks, I. E., Marba, N., KrauseJensen, D., Sejr, M. K., Blicher, M. E., Lagos, N. A., Olsen, Y. S., and Duarte, C. M.: Food supply confers calcifiers resistance to ocean acidification, Sci. Rep., 6, 19374, https://doi.org/10.1038/srep19374, 2016.

Reyes-Nivia, C., Diaz-Pulido, G., Kline, D., Ove Hoegh, G., and Dove, S.: Ocean acidification and warming scenarios increase microbioerosion of coral skeletons, Glob. Change Biol., 19, 1919-1929, https://doi.org/10.1111/gcb.12158, 2013.

Reyes-Nivia, C., Diaz-Pulido, G., and Dove, S.: Relative roles of endolithic algae and carbonate chemistry variability in the skeletal dissolution of crustose coralline algae, Biogeosciences, 11 , 4615-4626, https://doi.org/10.5194/bg-11-4615-2014, 2014.

Reynaud, S., Leclercq, N., Romaine-Lioud, S., Ferrier-Pages, C., Jaubert, J., and Gattuso, J. P.: Interacting effects of $\mathrm{CO}_{2}$ partial pressure and temperature on photosynthesis and calcification in a scleractinian coral, Glob. Change Biol., 9, 1660-1668, https://doi.org/10.1046/j.1529-8817.2003.00678.x, 2003.

Ries, J. B., Cohen, A. L., and McCorkle, D. C.: Marine calcifiers exhibit mixed responses to $\mathrm{CO}_{2}$-induced ocean acidification, $\mathrm{Ge}$ ology, 37, 1131-1134, https://doi.org/10.1130/g30210a.1, 2009.

Ritchie, R. J.: Universal chlorophyll equations for estimating chlorophylls a, b, c, and d and total chlorophylls in natural assemblages of photosynthetic organisms using acetone, methanol, or ethanol solvents, Photosynthetica, 46, 115-126, https://doi.org/10.1007/s11099-008-0019-7, 2008.

Rodolfo-Metalpa, R., Martin, S., Ferrier-Pagès, C., and Gattuso, J.-P.: Response of the temperate coral Cladocora caespitosa to mid- and long-term exposure to $p \mathrm{CO}_{2}$ and temperature levels projected for the year $2100 \mathrm{AD}$, Biogeosciences, 7, 289-300, https://doi.org/10.5194/bg-7-289-2010, 2010.

Sampaio, E., Rodil, I. F., Vaz-Pinto, F., Fernández, A., and Arenas, F.: Interaction strength between different grazers and macroalgae mediated by ocean acidification over warming gradients, Mar. Environ. Res., 125, 25-33, https://doi.org/10.1016/j.marenvres.2017.01.001, 2017.

Semesi, I. S., Kangwe, J., and Bjork, M.: Alterations in seawater $\mathrm{pH}$ and $\mathrm{CO}_{2}$ affect calcification and photosynthesis in the tropical coralline alga, Hydrolithon sp (Rhodophyta), Estuar. Coast. Shelf S., 84, 337-341, https://doi.org/10.1016/j.ecss.2009.03.038, 2009.

Short, J., Kendrick, G. A., Falter, J., and McCulloch, M. T.: Interactions between filamentous turf algae and coralline algae are modified under ocean acidification, J. Exp. Mar. Biol. Ecol., 456, 70-77, https://doi.org/10.1016/j.jembe.2014.03.014, 2014. 
Short, J. A., Pedersen, O., and Kendrick, G. A.: Turf algal epiphytes metabolically induce local $\mathrm{pH}$ increase, with implications for underlying coralline algae under ocean acidification, Estuar. Coast. Shelf S., 164, 463-470, https://doi.org/10.1016/j.ecss.2015.08.006, 2015.

Smith, S. V. and Key, G. S.: Carbon-dioxide and metabolism in marine environments, Limnol. Oceanogr., 20, 493-495, https://doi.org/10.4319/1o.1975.20.3.0493, 1975.

Solorzano, L.: Determination of ammonia in natural waters by the phenolhypochlorite method, Limnol. Oceanogr., 14, 799-801, 1969.

Thomas, C. W., Crear, B. J., and Hart, P. R.: The effect of temperature on survival, growth, feeding and metabolic activity of the southern rock lobster, Jasus edwardsii, Aquaculture, 185, 73-84, https://doi.org/10.1016/S0044-8486(99)00341-5, 2000.

Thomsen, J., Casties, I., Pansch, C., Kortzinger, A., and Melzner, F.: Food availability outweighs ocean acidification effects in juvenile Mytilus edulis: laboratory and field experiments, Glob. Change Biol., 19, 1017-1027, 2013.
Villas Bôas, A. B. and Figueiredo, M. A. d. O.: Are anti-fouling effects in coralline algae species specific?, Braz. J. Oceanogr., 52, 11-18, 2004.

Widdicombe, S. and Spicer, J. I.: Predicting the impact of ocean acidification on benthic biodiversity: What can animal physiology tell us?, J. Exp. Mar. Biol. Ecol., 366, 187-197, https://doi.org/10.1016/j.jembe.2008.07.024, 2008.

Yang, Y., Hansson, L., and Gattuso, J. P.: Data compilation on the biological response to ocean acidification: an update, Earth Syst. Sci. Data, 8, 79-87, https://doi.org/10.5194/essd-8-792016, 2016. 